\title{
Interrelationships of Sea Surface Salinity, Chlorophyll- $\alpha$ Concentration, and Sea Surface Temperature near the Antarctic Ice Edge
}

\author{
Cynthia Garcia-Eidell, ${ }^{a}$ Josefino C. Comiso, ${ }^{b}$ Max Berkelhammer, ${ }^{a}$ And Larry Stock ${ }^{\mathrm{c}}$ \\ ${ }^{a}$ Department of Earth and Environmental Sciences, University of Illinois at Chicago, Chicago, Illinois \\ ${ }^{\mathrm{b}}$ Cryospheric Sciences Laboratory, NASA Goddard Space Flight Center, Greenbelt, Maryland \\ ${ }^{\mathrm{c}} \mathrm{KBR}$, Inc., Greenbelt, Maryland
}

(Manuscript received 24 September 2020, in final form 11 April 2021)

\begin{abstract}
Satellite data can now provide a coherent picture of sea surface salinity (SSS), chlorophyll- $\alpha$ concentration $(\mathrm{Chl} \alpha)$, sea surface temperature (SST), and sea ice cover across the Southern Ocean. The availability of these data at the basin scale enables novel insight into the physical and biological processes in an area that has historically been difficult to gather in situ data from. The analysis shows large regional and interannual variability of these parameters but also strong coherence across the Southern Ocean. The covariability of the parameters near the marginal ice zone shows a generally negative relationship between SSS and Chl $\alpha(r=-0.87)$. This may in part be attributed to the large seasonality of the variables, but analysis of data within the spring period (from November to December) shows similarly high correlation $(r=-0.81)$. This is the first time that a large-scale robust connection between low salinity and high phytoplankton concentration during ice melt period has been quantified. Chlorophyll- $\alpha$ concentration is also well correlated with SST $(r=$ $0.79)$ providing a potential indicator of the strength of the temperature limitation on primary productivity in the region. The observed correlation also varied regionally due to differences in ice melt patterns during spring and summer. Overall, this study provides new insights into the physical characteristics of the Southern Ocean as observed from space. In a continually warming and freshening Southern Ocean, the relationships observed here provide a key data source for testing ocean biogeochemical models and assessing the effect of sea ice-ocean processes on primary production.
\end{abstract}

KEYWORDS: Sea ice; Southern Ocean; Radiances; Sea surface temperature; Salinity; Satellite observations

\section{Introduction}

Salinity and temperature are fundamental physical properties of seawater that drive the global thermohaline circulation and thus a key driver of global climate dynamics. They also influence the ocean's biogeochemical cycles as well as the ocean-atmosphere carbon flux through their effect on the solubility of aqueous $\mathrm{CO}_{2}$ (Woolf et al. 2016). Transport of biologically sequestered carbon to the deep ocean (biological pump) in the Southern Ocean and the drawdown of $\mathrm{CO}_{2}$ through the reduction of partial pressure of $\mathrm{CO}_{2}$ below that of the atmosphere from mechanisms such as phytoplankton primary production (solubility pump) are responsible for about $10 \%$ of the global ocean's $\mathrm{CO}_{2}$ uptake (Siegel et al. 2014). As essential climate variables within the global climate system, ocean salinity and surface temperature are critical and sensitive to changes in the hydrological cycle in response to anthropogenic climate change (Belward et al. 2016). In recent decades, large-scale freshening of surface waters has been observed in the Southern Ocean (Purich et al. 2018; Durack and Wijffels 2010; Jacobs et al. 2002), which according to Haumann et al. (2016) is a result of sea ice transport, increased runoff from ice sheet and shelf melt (Bintanja et al. 2013, 2015, and an increase in precipitation minus evaporation $(P-E)$ due to the positive trend in southern annular mode (SAM) and its associated poleward shift in the storm tracks and extratropical westerly wind jet (Son et al. 2009; Frederiksen and Frederiksen

Corresponding author: Josefino C. Comiso, josefino.c.comiso@ nasa.gov
2007). Such freshening together with changes in surface temperature has also been used to explain the unexpected positive trend in the Antarctic sea ice extent (Comiso et al. 2017; Hobbs et al. 2016) that reached a record high in 2014, but has since shown a significant decline (Parkinson 2019; Comiso et al. 2017).

The Southern Ocean is a diverse and vast environment that experiences seasonal extremes from large fluctuations in sea ice. About 15 million $\mathrm{km}^{2}$ of sea ice melt and freeze in these waters during the annual cycle (Zwally et al. 2002; Stroeve and Meier 2018). It is exposed to strong surface forcing related to storms in the westerly wind belt, as well as a more energetic surface circulation associated with the Antarctic Circumpolar Current (ACC), and northern components of the polar gyres. In the summer, the average sea ice extent is about 45 million $\mathrm{km}^{2}$. The color-coded map in Fig. 1a shows the monthly climatology (1982-2019) of sea surface temperature (SST) in February while the black line represents the climatological contour of the sea ice edge. The climatological SST in February shows temperatures from $0^{\circ}$ to $-1^{\circ} \mathrm{C}$ around the continental margins. Generally, waters in the Ross and Weddell Seas are colder due to the persistence of local gyres, but patches of relatively warmer waters can also be observed within these regions. The latter is also true around the Antarctic Peninsula. In September, SSTs close to freezing temperatures $\left(-2^{\circ} \mathrm{C}\right)$ are generally found near to the ice edge (Fig. 1b).

The observed broadscale freshening coupled with significant warming trend since 1950 (Gille 2008) and the interannual variability in the extent of the sea ice cover are expected to alter the production, growth, survival, and composition of phytoplankton in the Southern Ocean. Factors that affect 

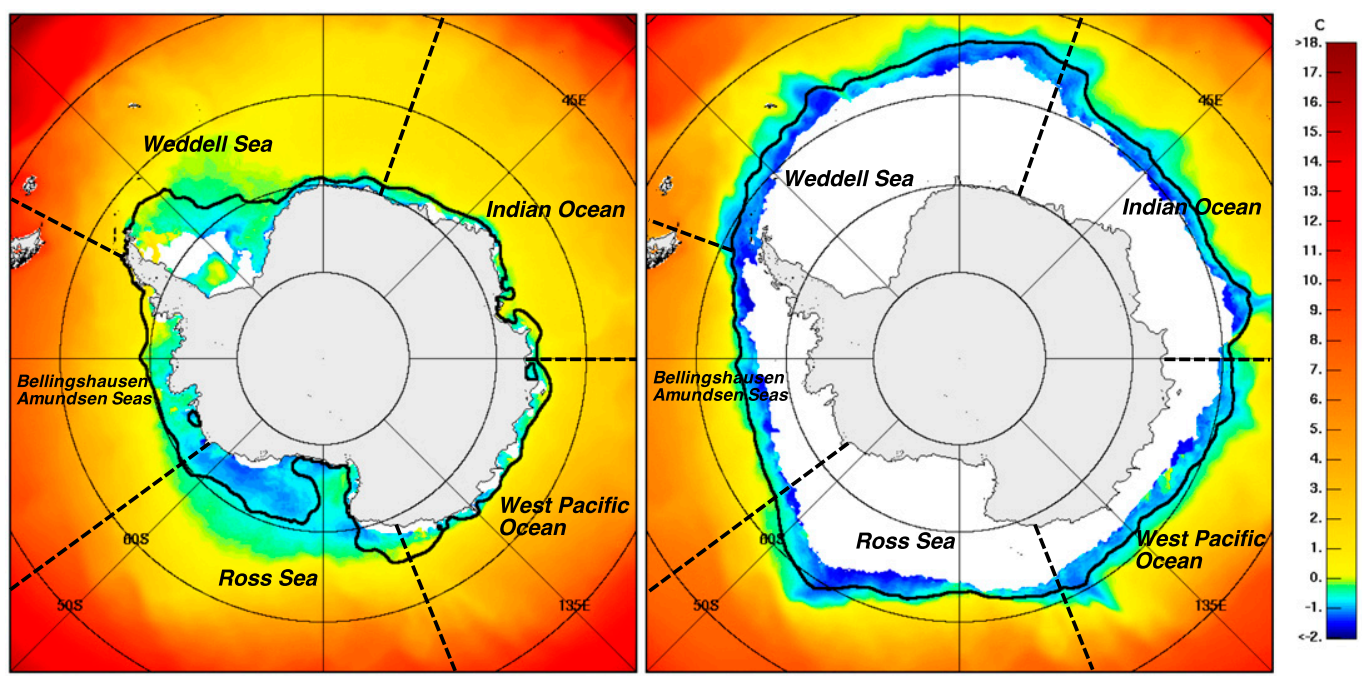

FIG. 1. Map of the Southern Ocean (left) February monthly SST climatology (1982-2019), which is a time when sea ice concentration is at minimum, and (right) September monthly SST climatology, when sea ice is at its maximum. The black solid contour lines represent the sea ice concentration at $10 \%$.

phytoplankton communities are most evident adjacent to the sea ice edge during austral spring and summer. The buoyant freshwater lens from the melt of sea ice together with abundant nutrients, iron supply, and solar insolation provide an ideal platform for phytoplankton blooms (Smith and Comiso 2008; Arrigo and van Dijken 2004; Smith and Nelson 1986). It has been estimated that these meltwater areas contribute about $40 \%-50 \%$ of the net primary productivity in the whole Southern Ocean (Sakshaug 1994; Smith and Nelson 1985). Results from modeling experiments provide more conservative values suggesting that the marginal ice zone (MIZ) contributes $54-68 \mathrm{~g} \mathrm{C} \mathrm{m}^{-2} \mathrm{yr}^{-1}$, which is similar to estimates in the pelagic region at $\sim 62 \mathrm{~g} \mathrm{C} \mathrm{m}^{-2} \mathrm{yr}^{-1}$, but still significantly larger than that in the sea ice (Taylor et al. 2013; Arrigo et al. 2008). The MIZ also influences the heat budget, sea ice distribution, and biogeochemical processes because it is an area characterized by dramatic lateral gradients in mixed layer salinity and temperature. Despite the relative importance of understanding large-scale physical and biological variability within the MIZ, changes within this zone are still poorly understood due to sparse in situ observations brought about by its remoteness. Efforts such as profiling floats and data from ships and mammals are helping to address the gap but currently provide insufficient temporal and spatial resolution to resolve the rapidly evolving dynamics in this vast sea ice impacted area. This contributes to uncertainty in modeling the effect of sea iceocean processes on large-scale physical and biogeochemical processes associated with changes in the climate system.

In this study, we took advantage of recently available quality-controlled and validated sea surface salinity (SSS) measurements (Garcia-Eidell et al. 2017, 2019) as well as the corresponding chlorophyll- $\alpha(\mathrm{Chl} \alpha)$, sea ice concentration, and SST from satellite data. The first part of the study provides the first detailed comparative analysis of the large-scale spatial and temporal patterns of these key parameters in the entire Southern Ocean. Argo data collected from the Southern
Ocean show that the surface salinity and mixed layer salinity differ by only 0.001 on average with a standard deviation of 0.01 , suggesting that satellite observations of SSS are representative of mixed layer salinity (Dong et al. 2009). The second part of the study assesses the changes occurring in the MIZ and the ice-free coastal polynya regions to quantitatively explore how the changes in SSS associated with the melt of sea ice and the formation of relatively low-density surface layer is affecting large-scale phytoplankton blooms. This study is made possible by the availability of concurrent observations of SSS, Chl $\alpha$ concentration, and sea ice cover in the Southern Ocean.

\section{Methods}

\section{a. Satellite data products}

The SSS satellite data product used in this study is from the Aquarius SAC-D (named for the Satélite de Applicaciones Científicas). The Aquarius SAC-D has three L-band microwave radiometers at incidence angles of $29.36^{\circ}, 38.44^{\circ}$, and $46.39^{\circ}$ and at a protected frequency of $1.414 \mathrm{GHz}$. The scatterometer that is used to correct for surface roughness measures ocean backscatter at a center frequency of $1.26 \mathrm{GHz}$. The total cross track of the SAC-D sensor that is in a push-broom configuration is $390 \mathrm{~km}$, providing global coverage within a week. For this study, we use the Southern Hemisphere polargridded Aquarius SAC-D product, referred to as AqGSFC (Garcia-Eidell et al. 2019), available at https://earth.gsfc.nasa.gov/ cryo/data/high-latitude-sea-surface-salinity. The AqGSFC SSS is based on the Aquarius Level 2 end-of-mission version 5.0 (Meissner et al. 2018). The processing of the AqGSFC data includes removal of land and high wind speed contaminations, use of median filter along track to suppress random short-wavelength noise, employment of relevant quality flags, and the use of higherresolution Special Sensor Microwave Imager (SSM/I) sea ice concentration data to mask out SSS that are potentially 
contaminated by sea ice. When compared with available in situ measurements, AqGSFC has been shown to outperform other available SSS products in part due to improved quality control in processing discussed above (random noise reduction, gap interpolation technique, and the use of the SSM/I sea ice mask), but also due to the system's concurrent active sensor that better accounts for the effects of surface roughness (Garcia-Eidell et al. 2019). In the succeeding analyses, all spaceborne measurements are gridded on to the same polar stereographic grid at $12.5-\mathrm{km}$ resolution on a running biweekly basis. Included in the analyses are data from August 2011 to June 2015, which corresponds to the period when measurements from all the sensors are available.

Chlorophyll- $\alpha$ concentrations were estimated using calibrated radiances measured by the Moderate Resolution Imaging Spectroradiometer (MODIS) Aqua at blue, green, and red wavelengths of the electromagnetic spectrum. The geophysical data are derived using two algorithms: the OC3m algorithm that makes use of band ratios and in situ measurements as described in O'Reilly et al. (1998) and the CI algorithm that makes use of reflectance differences as described by $\mathrm{Hu}$ et al. (2012). The Level $3 \mathrm{Chl} \alpha$ concentration data are provided by the Ocean Biology Processing Group (NASA OBPG 2014) at the NASA Goddard Space Flight Center, and are available at https://oceandata.sci.gsfc.nasa.gov/MODIS-Aqua/Mapped/ Daily/4km/chlor_a/.

Sea ice concentration is a parameter derived directly from $\mathrm{SSM} / \mathrm{I}$ passive microwave brightness temperature $\left(T_{B}\right)$ satellite data. It represents the fraction of sea ice within the footprint of satellite sensors and provides the means to estimate extent, area, and location of the sea ice edge. The sea ice concentration data used in this study are the SB2 sea ice product, which is computed using the enhanced bootstrap algorithm (Comiso 2017). The SB2 sea ice concentration data are available at the National Snow and Ice Data Center (NSIDC) at https:// doi.org/10.5067/7Q8HCCWS4I0R.

Global SST data have been derived from in situ measurements primarily from ships, buoys, and other platforms (Reynolds et al. 2002). However, due to the harsh conditions in polar regions the only way to obtain SST of sufficient spatial and temporal resolution is through satellite sensors (Comiso 2000). A combined dataset that makes use of both in situ and satellite data has been adapted by the National Oceanic and Atmospheric Administration (NOAA) National Centers for Environmental Information (NCEI); the latest version is available at https://www.ncei.noaa.gov/data/sea-surface-temperatureoptimum-interpolation/v2.1/access/avhrr/. The data are available as daily Optimum Interpolation SSTs that use data from the Advanced Very High-Resolution Radiometer (AVHRR) infrared satellite (Banzon et al. 2016).

\section{b. Pan-Antarctic and regional variability}

To assess the spatial and temporal variability of Chl $\alpha$ concentration, SSS, SST, and sea ice, the satellite data were analyzed from the entire Southern Ocean, referred to as the Southern Ocean study area, which covers the open ocean area greater than $50^{\circ} \mathrm{S}$ for the Weddell Sea and Indian Ocean and greater than $55^{\circ} \mathrm{S}$ for the other sectors. Monthly, seasonal, and yearly averaged datasets of SSS, SST, Chl $\alpha$ concentration,

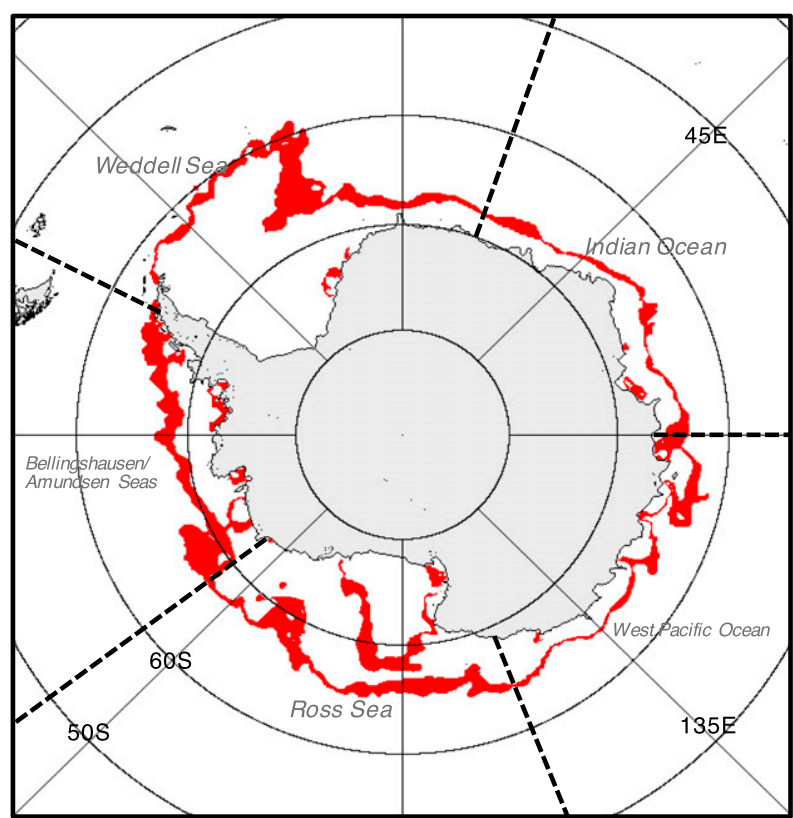

FIG. 2. Area of sea ice movement from 1 to 14 Jan 2014 (in red) and the five regional sectors: the Weddell Sea, Indian Ocean, west Pacific Ocean, Ross Sea, and Bellingshausen/Amundsen Seas separated by the dashed lines.

and sea ice concentration and extent during the study period are presented to help provide necessary baseline information in the region. Key atmospheric drivers that affect surface layer salinity and temperature such as precipitation minus evaporation and instantaneous $10-\mathrm{m}$ wind gust from the ERA5 reanalysis dataset (C3S 2017) were also analyzed to provide insight into the drivers of changes in the different parameters. Unlike the Arctic, the Antarctic sea ice was slowly increasing and reaching maximum values in 2014 but started to contract in the winter of 2015, with the biggest change occurring in 2016 and 2017 (Comiso et al. 2017). Unfortunately, the impact of this decline could not be evaluated in our study because the dataset for SSS ends in autumn of 2015 when Aquarius SAC-D data terminated.

\section{c. Comparative analysis near the marginal ice zone}

The marginal ice zone (MIZ) is a highly active biological, physical, and atmospheric region between the open ocean and the sea ice cover. It is a relatively low sea ice concentration area [i.e., between 0.15 and 0.8 according to Strong and Rigor (2013) and Williams et al. (2013)] and has been regarded as a highly productive zone especially during the spring and summer. We focus our analysis on the ice-free areas near the MIZ where sea ice retreated (or advanced) during a period of 14 days using the SB2 sea ice concentration data (Comiso and Nishio 2008). An example of an ice change mask during the melt period (i.e., 114 January 2014) is illustrated in Fig. 2 where the area in red represents the ice-free area used in the comparative study of the satellite-derived parameters. During the growth period, the study area is the ice-free area that will be covered by sea ice 14 days in advance. 


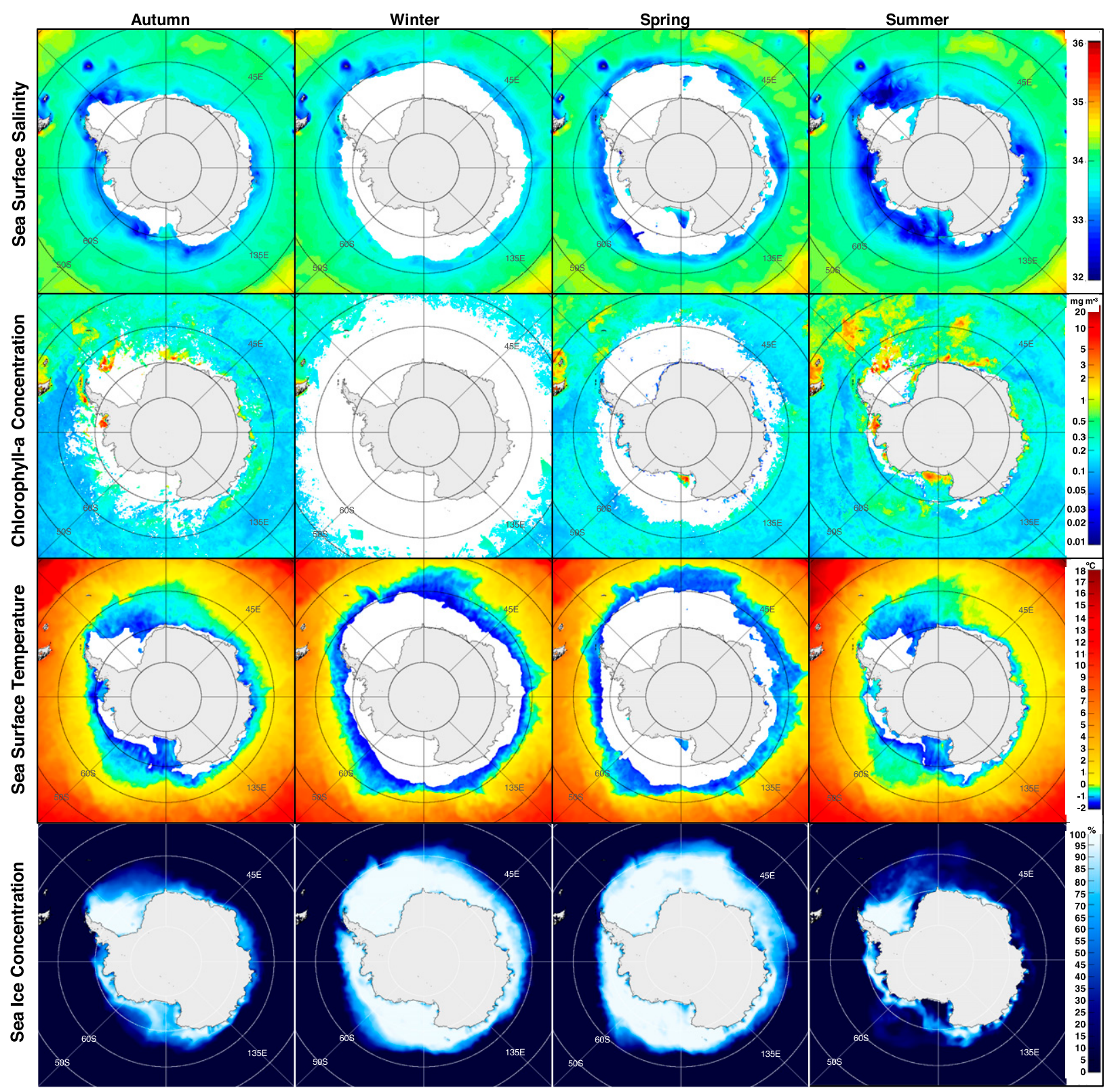

FIG. 3. Seasonal maps of SSS from Aquarius SAC-D, Chl $\alpha$ concentration from MODIS Aqua, SST from AVHRR, and sea ice concentration from SSM/I. The maps represent average seasonal values from 2011 to 2015.

Seasonal averages of the four parameters in Fig. 3 show that Chl $\alpha$ concentration near the MIZ is not as spatially comprehensive compared to the other parameters. This is mainly because MODIS Chl $\alpha$ concentration can only be derived during daylight and cloud-free conditions. In the Antarctic, the problem is exacerbated by long periods of darkness during winter and the conservative sea ice mask that was applied on the MODIS data. The Chl $\alpha$ concentration during autumn and winter are thus excluded in the correlation analysis discussed in the forthcoming sections. In contrast, SSS and SST data show full coverage since SSS estimates are derived from passive microwave data that are not affected by clouds or darkness.
The SST estimates have the proper sea ice mask and are derived from thermal infrared data that are not affected by darkness but are affected by clouds.

The relationships were quantified between variables using the Pearson's correlation coefficient and the corresponding $t$ score and $p$ value, with significance levels of $\alpha=0.05$ to test significance for the whole Southern Ocean study area and its various sectors. The computed relationships are based on the running biweekly measurements extracted from the concurrent ice change mask. We did similar analysis using biweekly data during the critical spring window (from November to December) when sea ice is retreating rapidly and the impacts 
Southern Ocean (lat $>55^{\circ} \mathrm{S}$ )
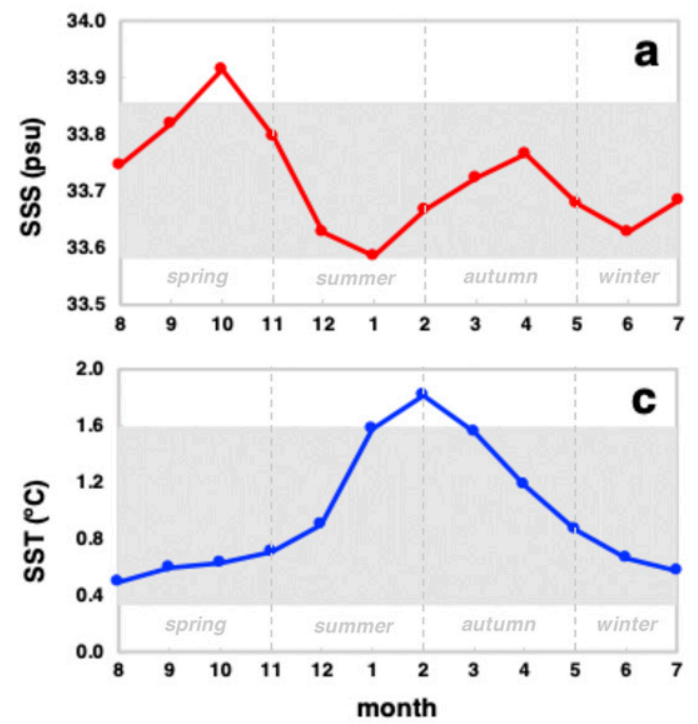
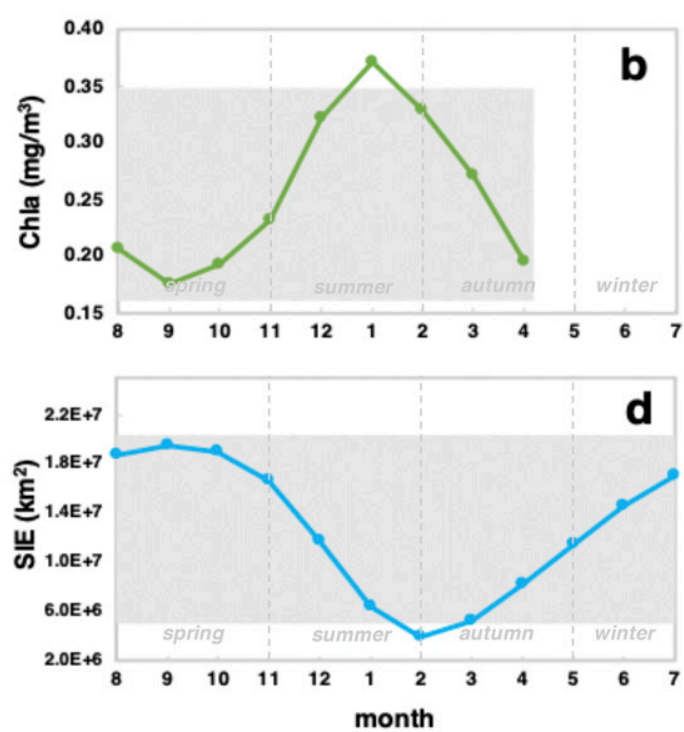

FIG. 4. Multiyear monthly averages of (a) SSS, (b) Chl $\alpha$ concentration, (c) SST, and (d) sea ice extent the Southern Ocean $\left(>55^{\circ} \mathrm{S}\right)$. The multiyear monthly averages were estimated from August 2011 to June 2015, with the gray shading showing values within one standard deviation.

of the availability of meltwater on phytoplankton are expected to be most evident. All correlation coefficients reported in the results are with $p<0.001$. Regional analyses were also conducted in the five sectors, namely the Weddell Sea from $60^{\circ} \mathrm{W}$ to $20^{\circ} \mathrm{E}$, the Indian Ocean from $20^{\circ}$ to $90^{\circ} \mathrm{E}$, the west Pacific Ocean from $90^{\circ}$ to $160^{\circ} \mathrm{E}$, the Ross Sea from $160^{\circ} \mathrm{E}$ to $130^{\circ} \mathrm{W}$, and the Bellingshausen and Amundsen Seas from $130^{\circ}$ to $60^{\circ} \mathrm{W}$, which are also shown in Fig. 2. For the regional analysis, retrievals in latitudes $>50^{\circ} \mathrm{S}$ are considered for the Weddell Sea and Indian Ocean, and $>55^{\circ} \mathrm{S}$ for the west Pacific Ocean, Ross Sea, and Bellingshausen-Amundsen Seas.

\section{Results}

\section{a. Spatial and temporal variability in the Southern Ocean}

An examination of Fig. 3 shows meridional variations in SSS and SST with lowest values found closest to the ice edge. Apart from the generally low salinity values concentrated in the vicinity of the sea ice margins, spatial patterns of SSS during summer and autumn show slightly saltier surface waters in the Indian Ocean and west Pacific sectors, which are areas where warm and saltier subsurface waters upwell. Low SSS during summer are consistently located along the Ross Sea, Weddell Sea, and Bellingshausen and Amundsen Seas, and around Prydz Bay $\left(69^{\circ} \mathrm{S}, 75^{\circ} \mathrm{E}\right)$. The strong meridional freshening during summer is also evident, which is related to ice melt that is transported northward via Ekman advection and year-round westerly winds (Dong et al. 2009; Holland and Kwok 2012). Spatially, seasonal SSS, SST, and sea ice concentration distribution are coherent across the various sectors.

The summer map for Chl $\alpha$ concentration in Fig. 3 shows high values in the western Weddell adjacent to the sea ice cover. This is also observed along the shores, especially in coastal polynya areas in the Ross Sea and Amundsen/ Bellingshausen Seas. Nutrient-rich Antarctic coastal waters and sea ice edges can have phytoplankton concentrations that reach up to $10^{8}$ cells per liter (Deppeler and Davidson 2017). High Chl $\alpha$ concentrations are observed off the west of the Antarctic Peninsula, and at the eastern side but to a lesser extent. Remnants of the summer bloom along the coast of the Bellingshausen and Weddell Seas are also apparent in the autumn map, while the bloom in the Ross ice shelf polynya started to show up in spring and becomes more widespread in summer.

As for SST, low values are seen along the sea ice edges and continental margins. Like SSS, relatively higher surface temperature values are observed in the Indian Ocean and west Pacific sectors during summer and autumn. Average summer SST is also shown to be relatively high along the Bellingshausen Sea. Another notable observation is the coherence of SST and sea ice concentration spatial distribution, which confirms a strong influence of surface temperature on the sea ice cover (Maykut and Untersteiner 1971; Parkinson and Washington 1979). Lastly, sea ice concentration maps show large seasonal variations of sea ice cover and serves as a reference for the seasonal location of the sea ice edge.

Typical seasonal cycles of SSS, SST, Chl $\alpha$ concentration, and sea ice extent extracted from the Southern Ocean study area are presented in Fig. 4 using multiyear monthly averages from the study period. The four parameters show robust seasonal cycles with low SSS during summer, coinciding with high phytoplankton blooms, high SST, and low sea ice extent. The SSS plot in Fig. 4a shows values ranging from 33.6 in summer to 33.9 during the height of spring in October when sea ice cover usually reaches its maximum extent. Another peak in April is 

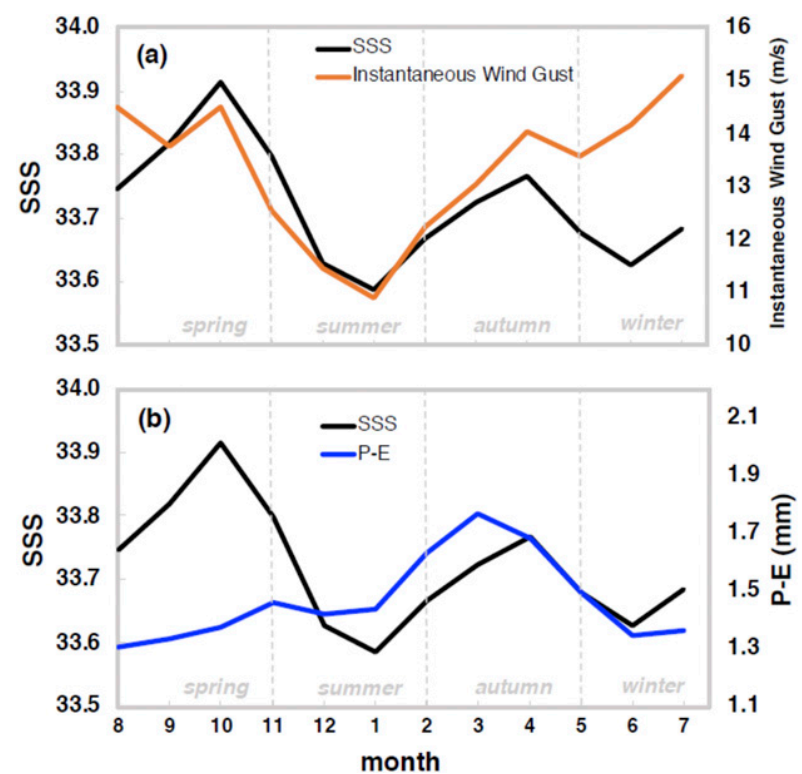

FIG. 5. Multiyear monthly average of (a) SSS and instantaneous 10-m wind gust $\left(\mathrm{m} \mathrm{s}^{-1}\right)$, and (b) SSS and $P-E(\mathrm{~mm})$ from ERA5 from August 2011 to June 2015 in the Southern Ocean $\left(>55^{\circ} \mathrm{S}\right)$.

observed in the Southern Ocean primarily in the northern part of the study area, which is also observable in the different sectors (not shown). This peak in April is likely the effect of vertical entrainment that brings the warmer and saltier subsurface waters into the surface, modifying the mixed layer density (Dong et al. 2009). This may be in part influenced by increased $10-\mathrm{m}$ wind gust during the period as indicated by ERA5 reanalysis product (C3S 2017) and shown in Fig. 5a. Vertical entrainment in the Southern Ocean was observed to be at its maximum in April and May (Dong et al. 2009), and may be influenced by surface cooling and brine rejection during sea ice formation, as well as horizontal transport. On the other hand, monthly changes in $P-E$ (Fig. 5b) do not seem to pace the seasonal cycle in SSS, as the increase in $P-E$ in autumn coincides with a decrease in SSS.

Monthly averages of Chl $\alpha$ concentration in Fig. 4b show values ranging from 0.19 to $0.37 \mathrm{mg} \mathrm{m}^{-3}$ that peak in midsummer (January), and decline drastically in April. In early spring, the Chl $\alpha$ concentration starts at an average monthly minimum value of $0.18 \mathrm{mg} \mathrm{m}^{-3}$ in September and increases to $0.37 \mathrm{mg} \mathrm{m}^{-3}$ in January. The Chl $\alpha$ concentration maxima in summer are coincident with the abrupt decrease in sea ice extent and lowest SSS. The Chl $\alpha$ concentration during this time represent blooms found along the ice edge and coastal waters where meltwater is introduced.

The highest SST values are observed in February or during the end of summer at $1.81^{\circ} \mathrm{C}$. The coldest SST values are observed in August or in winter at $0.50^{\circ} \mathrm{C}$. Surface temperature stays relatively low until November when SST starts to increase toward its peak value in February. The well-known seasonality of the Antarctic sea ice extent is depicted in Fig. 4d, with minimum February sea ice extent of 3.97 million $\mathrm{km}^{2}$ and maximum September sea ice extent of 19.55 million $\mathrm{km}^{2}$. The growth and decay of sea ice is shown to be asymmetric in that it takes about eight months to reach maximum during growth but only four months to reach minimum values during decay (Zwally et al. 1983). This asymmetry is also observed in the SST monthly averages in Fig. 4c, suggestive of the role of surface temperature in driving the seasonal cycles in sea ice cover.

The satellite-derived yearly averages of the four parameters from the Southern Ocean study area and from the five sectors from 2011 to 2015, are summarized in Table 1 . The yearly averages were computed from August 2011 to May 2012 for the first year and from June to May for 2012-15. The interannual variability in SSS and Chl $\alpha$ concentration is relatively modest for the entire Southern Ocean. However, the yearly values for SST show a gradual decline that is coherent with trends in sea ice extent, which had the highest yearly average value at $13.1 \times$ $10^{6} \mathrm{~km}^{2}$ when SST was at its lowest at $1.17^{\circ} \mathrm{C}$, both for the period from June 2014 to May 2015. Overall, yearly SSS, SST, $\mathrm{Chl} \alpha$ concentration, and sea ice extent are shown to be regionally variable. The Weddell Sea sector has the lowest SSS at 33.58, coldest waters at $-0.11^{\circ} \mathrm{C}$, highest area of sea ice extent at 4.64 million $\mathrm{km}^{2}$, and highest $\mathrm{Chl} \alpha$ concentration at $0.36 \mathrm{mg} \mathrm{m}^{-3}$. The Ross Sea also has a high area of sea ice extent at 2.96 million $\mathrm{km}^{2}$, relatively warmer waters at $1.77^{\circ} \mathrm{C}$, SSS at 33.76 , and a relatively high $\mathrm{Chl} \alpha$ concentration at $0.24 \mathrm{mg} \mathrm{m}^{-3}$. The Bellingshausen/Amundsen Seas have the highest SSS at 33.77, highest SST at $2.5^{\circ} \mathrm{C}$, and $\mathrm{Chl} \alpha$ concentration of $0.22 \mathrm{mg} \mathrm{m}^{-3}$.

\section{b. Seasonal and interannual changes near the ice edge}

Satellite-derived data of the four parameters extracted from the MIZ study area for years 2011-15 are presented in Fig. 6. The SSS data from the MIZ shown in Fig. 6a have relatively strong seasonality, with low SSS values in summer and high values from March to October, but also with significant interannual variability. Most notable is the relatively higher SSS during late winter and spring in 2011 and 2012 that may be associated with the fact that the MIZ was farther north during this year where SSS is persistently higher. This is not the case for 2013 and 2014 when the ice extents were even higher. This variability may be due to differences in wind stress that cause the transport of high SSS to the region or from upwelling of saltier waters. The summer SSS shows large intra-annual variability with lowest values occurring during summer of 2015 that may be associated with extensive meltwater following the record high ice extent in 2014, while the occurrence of the SSS minima happened earliest for 2014, followed by 2013, 2015, and 2012. The freshening at the end of winter and early spring also happens earlier in 2014, followed by 2013, 2011, and 2012, which reached significantly higher values before declining. Note that there are no distinct double peaks in the SSS plots in the MIZ study region as was observed for the entire Southern Ocean (Fig. 4a).

The Chl $\alpha$ concentration distribution in Fig. 5b shows large interannual variability in summer but only modest interannual differences at the end of winter and during spring. The Chl $\alpha$ concentration was highest in 2013 and 2015 in early January and concurrently went down through summer and into early autumn. The Chl $\alpha$ concentration for 2014 started low, but 
TABLE 1. Yearly averages of SSS, SST, sea ice movement area, and Chl $\alpha$ concentration in the whole Southern Ocean and the different sectors from 2011 to 2015.

\begin{tabular}{|c|c|c|c|c|c|c|}
\hline & & $\begin{array}{l}\text { August 2011- } \\
\text { May } 2012\end{array}$ & $\begin{array}{c}\text { June 2012- } \\
\text { May } 2013\end{array}$ & $\begin{array}{c}\text { June 2013- } \\
\text { May } 2014\end{array}$ & $\begin{array}{c}\text { June 2014- } \\
\text { May } 2015\end{array}$ & $\begin{array}{c}\text { 4-yr } \\
\text { average }\end{array}$ \\
\hline \multirow[t]{6}{*}{ SSS } & All $\left(>55^{\circ} \mathrm{S}\right)$ & 33.793 & 33.734 & 33.675 & 33.700 & 33.725 \\
\hline & Weddell Sea & 33.646 & 33.614 & 33.579 & 33.497 & 33.584 \\
\hline & Indian Ocean & 33.744 & 33.682 & 33.640 & 33.666 & 33.683 \\
\hline & West Pacific Ocean & 33.863 & 33.759 & 33.678 & 33.756 & 33.764 \\
\hline & Ross Sea & 33.824 & 33.783 & 33.692 & 33.727 & 33.757 \\
\hline & Bellingshausen/Amundsen & 33.826 & 33.770 & 33.728 & 33.772 & 33.774 \\
\hline \multirow[t]{6}{*}{$\operatorname{SST}\left({ }^{\circ} \mathrm{C}\right)$} & All $\left(>55^{\circ} \mathrm{S}\right)$ & 1.204 & 1.373 & 1.198 & 1.174 & 1.237 \\
\hline & Weddell Sea & -0.113 & 0.015 & -0.144 & -0.192 & -0.108 \\
\hline & Indian Ocean & 0.220 & 0.213 & 0.116 & -0.001 & 0.137 \\
\hline & West Pacific Ocean & 1.143 & 1.239 & 1.121 & 1.200 & 1.176 \\
\hline & Ross Sea & 1.659 & 1.888 & 1.763 & 1.788 & 1.774 \\
\hline & Bellingshausen/Amundsen & 2.445 & 2.759 & 2.435 & 2.285 & 2.481 \\
\hline \multirow[t]{6}{*}{$\operatorname{SIE}\left(\mathrm{km}^{2}\right)$} & All $\left(>55^{\circ} \mathrm{S}\right)$ & 11634365.27 & 12365947.04 & 12925599.35 & 13088736.23 & 12503661.97 \\
\hline & Weddell Sea & 4485266.52 & 4569162.20 & 4632713.74 & 4860080.81 & 4636805.82 \\
\hline & Indian Ocean & 1842643.35 & 2013513.74 & 2160705.04 & 2204815.96 & 2055419.52 \\
\hline & West Pacific Ocean & 1251185.39 & 1468014.33 & 1470444.46 & 1361207.80 & 1387712.99 \\
\hline & Ross Sea & 2744736.78 & 2929304.26 & 2999575.08 & 3146964.50 & 2955145.16 \\
\hline & Bellingshausen/Amundsen & 1310533.24 & 1385952.51 & 1662161.03 & 1515667.15 & 1468578.48 \\
\hline \multirow[t]{6}{*}{$\operatorname{Chl} \alpha\left(\mathrm{mg} \mathrm{m}^{-3}\right)$} & All $\left(>55^{\circ} \mathrm{S}\right)$ & 0.238 & 0.237 & 0.242 & 0.241 & 0.239 \\
\hline & Weddell Sea & 0.418 & 0.344 & 0.371 & 0.300 & 0.358 \\
\hline & Indian Ocean & 0.202 & 0.182 & 0.188 & 0.251 & 0.206 \\
\hline & West Pacific Ocean & 0.178 & 0.195 & 0.192 & 0.215 & 0.195 \\
\hline & Ross Sea & 0.215 & 0.246 & 0.257 & 0.238 & 0.239 \\
\hline & Bellingshausen/Amundsen & 0.205 & 0.223 & 0.219 & 0.216 & 0.216 \\
\hline
\end{tabular}

subsequently followed a pattern like that observed in 2013 and 2015 toward the end of summer. The peak in 2012 Chl $\alpha$ concentration occurred latest (late summer/early autumn), which is consistent with the delayed timing of the SSS minimum for the same year. During spring and summer, the patterns were similar for all years, with 2014 and 2015 having the highest values at the end of the year. The plots for SST also show significant interannual variability, with 2013 having highest values in summer, 2012 with the lowest summer values, and 2014 and 2015 having almost the same intermediate values. The discrepancies are not as large in winter with 2014 having the lowest values, and 2012 and 2013 with relatively higher values. In late spring and early summer, 2012 had the highest SST values, 2013 and 2014 had almost the same intermediate values, and 2011 had significantly lower values. The changes in sea ice edge have similar patterns for all years except in early summer (December) with values in 2011 being the highest followed by 2012, 2013, and 2014.

\section{1) RELATIONSHIP BETWEEN SSS AND CHL $\alpha$ CONCENTRATION}

To compare temporal variability of SSS with Chl $\alpha$ concentration in the MIZ, we present the biweekly averages of concurrent SSS and Chl $\alpha$ in Fig. 7. An inverse relationship between the two variables is observed with the decrease in SSS primarily driven by the retreat of sea ice coinciding with Chl $\alpha$ concentration increase. Conversely, as the SSS increases during ice growth in autumn, the Chl $\alpha$ concentration declines. This phenomenon persists for the majority of the ice edge regions, but the coherence varies between sectors. Low salinity along with ample nutrients, micronutrients, and increased irradiances of photosynthetically active radiation (PAR) and UV radiation has been postulated to cause an enhancement of Chl $\alpha$ concentration along the ice-free areas of the MIZ (Comiso et al. 1993; Smith and Nelson 1986). The decrease in salinity creates a stable, shallow surface layer that supports sharp pulses of phytoplankton blooms as discussed in Smith et al. (2000), Hiscock et al. (2003), and Sullivan et al. (1988). The scatterplots on the right of Fig. 7 show the general relationship of Chl $\alpha$ concentration versus SSS. The two variables show a strong negative relationship with one another with a correlation coefficient of $-0.87, p<0.001$ when considering data from the Southern Ocean study area (Fig. 7a).

Similar analyses were done for each sector in Figs. 7b-f, showing that the relationship varies regionally. The highest correlation coefficient between SSS and Chl $\alpha$ concentration can be found in the Bellingshausen/Amundsen Seas at -0.85 , and the lowest in the Weddell Sea at -0.31 . The correlation coefficients for the other sectors are $-0.83,-0.65$, and -0.53 for the western Pacific Ocean, Indian Ocean, and Ross Sea, respectively. The low correlation coefficient in the Weddell Sea is associated with the large interannual variability of Chl $\alpha$ concentration in the summer as shown in Fig. 7b. Of all the sectors, the Weddell Sea also shows the highest mean SSS 

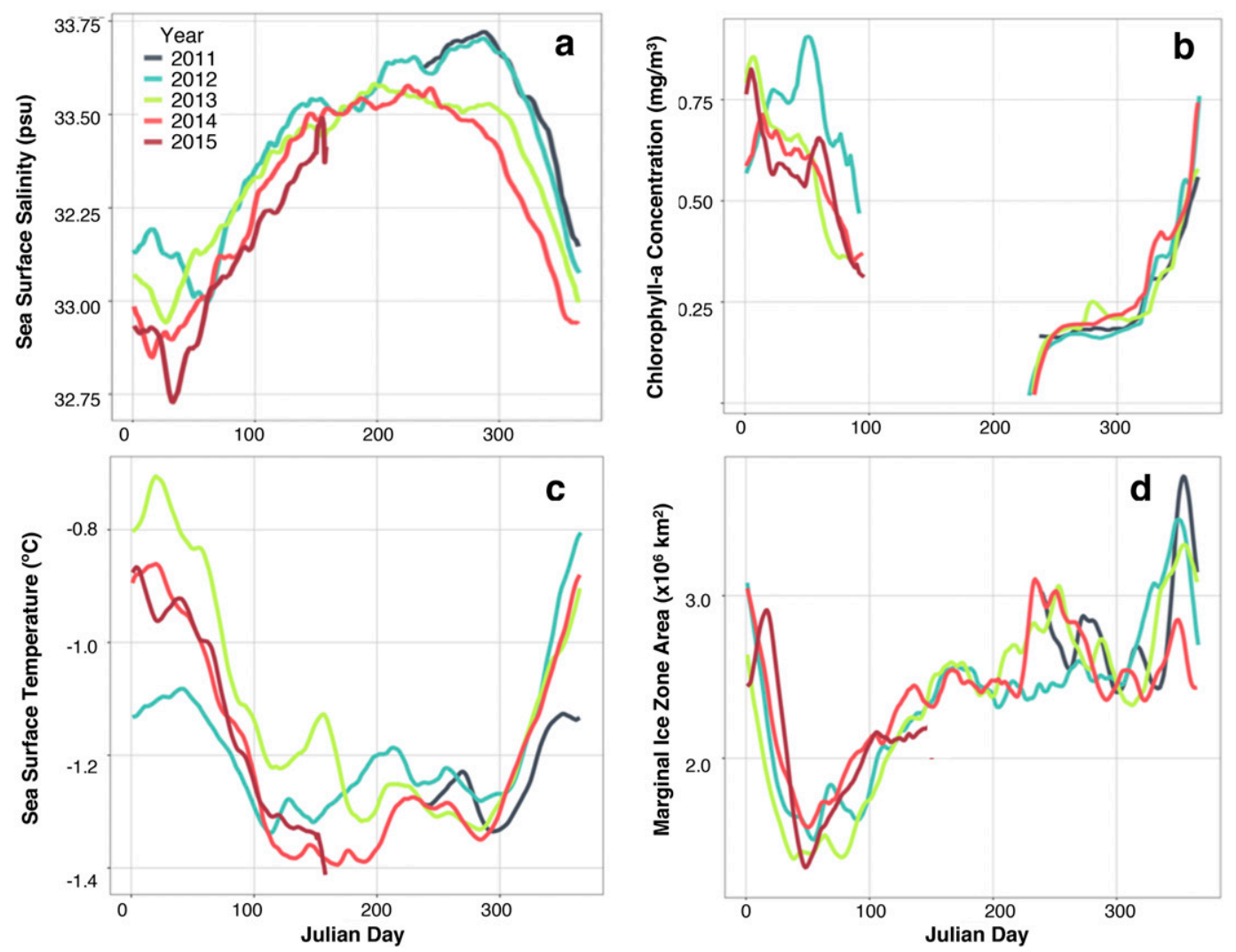

FIG. 6. Interannual variation between SSS, Chl $\alpha$ concentration, SST, and area of sea ice movement from August 2011 to June 2015 in the whole Southern Ocean.

at 33.42 as well as a high summer SSS variability that ranges from 32.6 in summer of 2015 to 33.2 in summer of 2012.

The relatively high correlation is likely influenced in part by the seasonality of SSS, which is associated with the natural variability of the sea ice cover as driven by solar radiation. To focus on the period when the sea ice is retreating rapidly and the impacts of the availability of meltwater on the phytoplankton are expected to be most evident, we look at the relationship of SSS and Chl $\alpha$ concentration within the November to December window. The results using biweekly averages, as presented in Fig. 8, show that the relationships are similar to those derived using all available data. The estimated correlation coefficient for the entire Southern Ocean is -0.810 , while for the Weddell Sea, Indian Ocean, west Pacific Ocean, Ross Sea, and Bellingshausen/Amundsen Seas, the values are -0.280 , $-0.655,-0.866,-0.602$, and -0.914 , respectively. The large variability of the values for the different sectors is also indicative that there are other factors that affect the relationship of the two variables, and that stratification-induced phytoplankton blooms near the MIZ may not be as strong as postulated in previous reports (Smith and Nelson 1985; Smith and Comiso 2008).

The average values as summarized in Table 2 are 33.35 for SSS and $0.40 \mathrm{mg} \mathrm{m}^{-3}$ for Chl $\alpha$ concentration in the entire Southern Ocean during the study period. The value for Chl $\alpha$ concentration is slightly more than the estimate of Sarmiento et al. (2004) in the Southern Ocean marginal sea ice biome of $0.32 \mathrm{mg} \mathrm{m}^{-3}$. The four years of satellite data are not suitable for estimating a secular trend, but overall a freshening of 0.13 is observed during the $2011-15$ period. The highest mean Chl $\alpha$ concentration is observed in the Bellingshausen/ Amundsen Seas at $0.65 \mathrm{mg} \mathrm{m}^{-3}$, along with the lowest mean SSS at 33.25. It also has the steepest negative slope between SSS and Chl $\alpha$ concentration among all the regions. The Bellingshausen/Amundsen Seas area, which covers west of the Antarctic Peninsula, has been observed to be one of the climate change hotspots globally (Jacobs and Comiso 1997), experiencing a decrease in seasonal sea ice from $-5.7 \%$ to $-6.6 \%$ decade $^{-1}$ (Comiso and Nishio 2008; Parkinson and Cavalieri 2012). This region has also been contributing significantly to the ongoing regional freshening and Southern Ocean hydrography. The Weddell Sea and the Bellingshausen Sea combined have productivity rates of over $600 \mathrm{mg} \mathrm{C} \mathrm{m}^{-2} \mathrm{day}^{-1}$ in the peak of summer (Arrigo et al. 2008; Vernet et al. 2008). The ice-free season in the Bellingshausen/Amundsen Seas is also found to have lengthened by about three months (Stammerjohn et al. 2012) because of early retreat and later advance of the ice cover.

High Chl $\alpha$ concentration is also observed in the Ross Sea with an average of $0.38 \mathrm{mg} \mathrm{m}^{-3}$, and average SSS of 33.34. The Ross Sea is one of the most productive continental shelf zones, contributing to about a third of the total annual net primary production in shelf waters (Arrigo et al. 2008). Higher 
(a) Southern Ocean

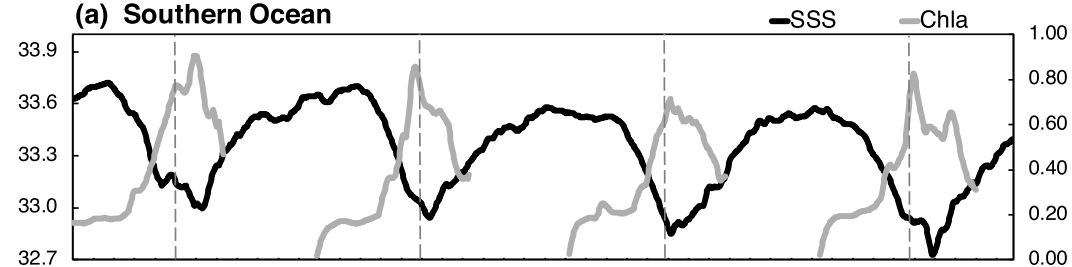

(b) Weddell Sea

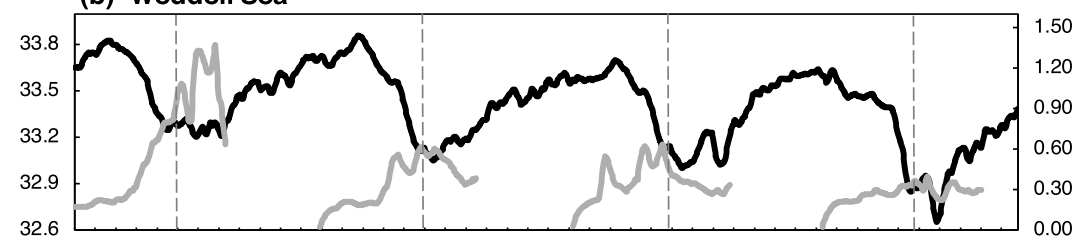

(c) Indian Ocean

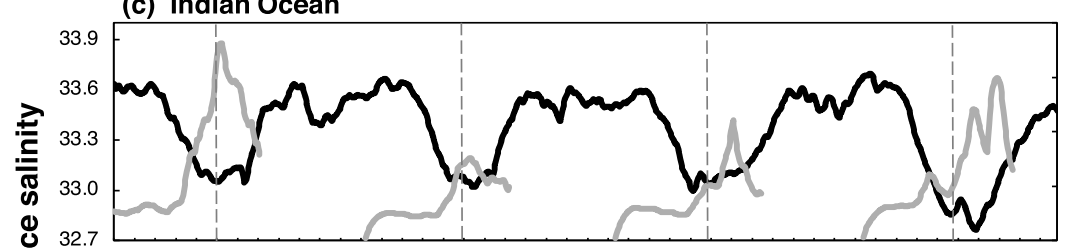

(d) West Pacific Ocean

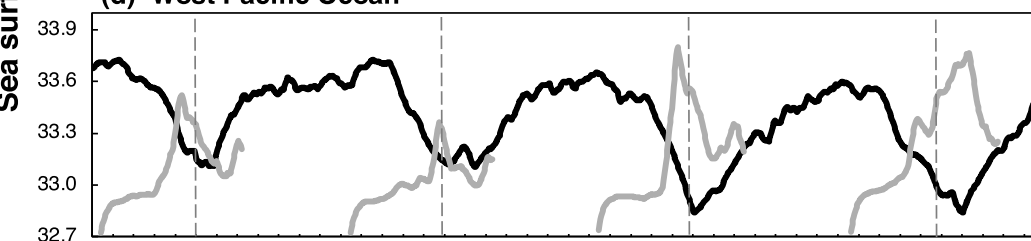

(e) Ross Sea
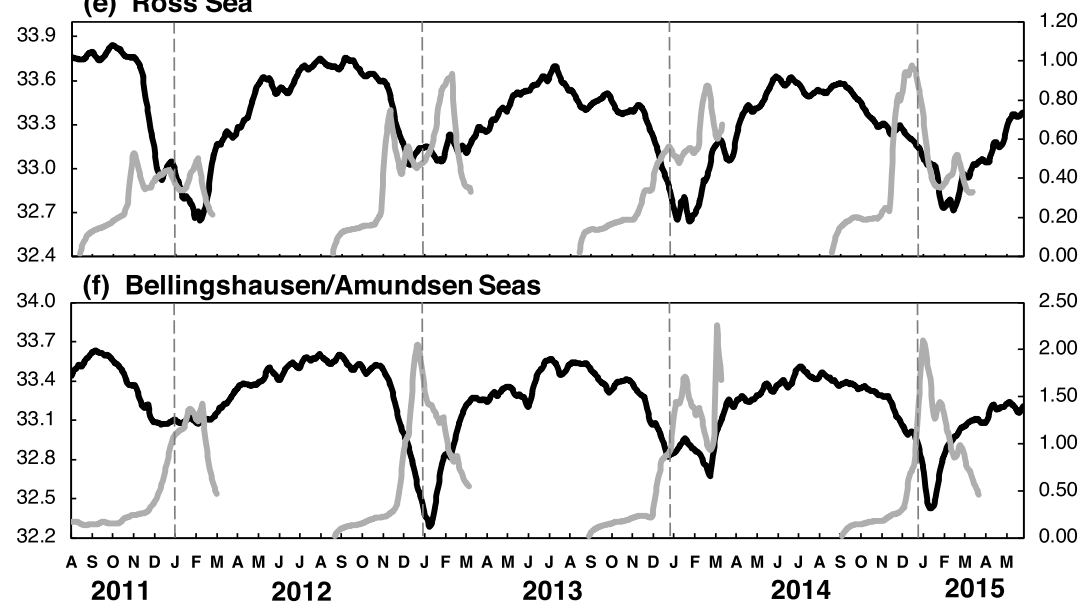
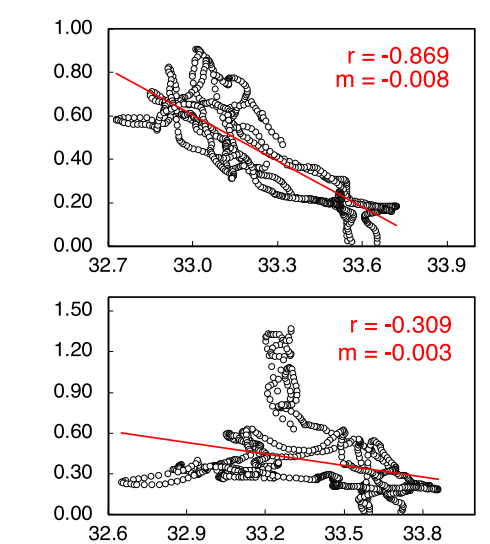

1.20

0.90
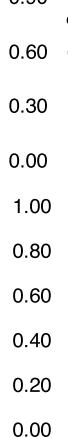

1.20

1.00

0.80

0.60

0.40

0.00

is

.00

1.50

.00

00

FIG. 7. (left) Time series of SSS in black and Chl $\alpha$ concentration in gray from the MIZ area from August 2011 to June 2015 in the (a) Southern Ocean, (b) Weddell Sea, (c) Indian Ocean, (d) west Pacific Ocean, (e) Ross Sea, and (f) Bellingshausen/Amundsen Seas. (right) Corresponding scatterplots of SSS vs Chl $\alpha$ concentration and the correlation coefficient $(r)$ and slope $(m)$.

freshening rates have been observed in the Ross Sea (Nakayama et al. 2020), which along with iron enrichment from coastal sediments and basal shelf melt, and light availability can enhance phytoplankton growth rates. The Ross polynya also has daily primary production as high as $6 \mathrm{gC} \mathrm{m}^{-2}$ day $^{-1}$ (Smith and Gordon 1997). Conversely, the lowest mean $\mathrm{Chl} \alpha$ concentrations at $0.33 \mathrm{mg} \mathrm{m}^{-3}$ are seen in the other two sectors, the Indian and west Pacific Oceans, with average SSS of 33.40. This could be the effect of a positive SAM on the mixed layer depth, with an overall deepening in the Indian Ocean and shallowing over the western Pacific Ocean (Sallée et al. 2010), which could limit phytoplankton concentration.

To assess the location and spatial distribution of negative relationship that exists between SSS and Chl $\alpha$ concentration, grid cells with statistically significant negative correlations are presented in Fig. 9. The relationship is strongest near the ice edges and coastal shelf areas (dark greens), showing not just the effect of freshening from sea ice and glacial meltwater but 

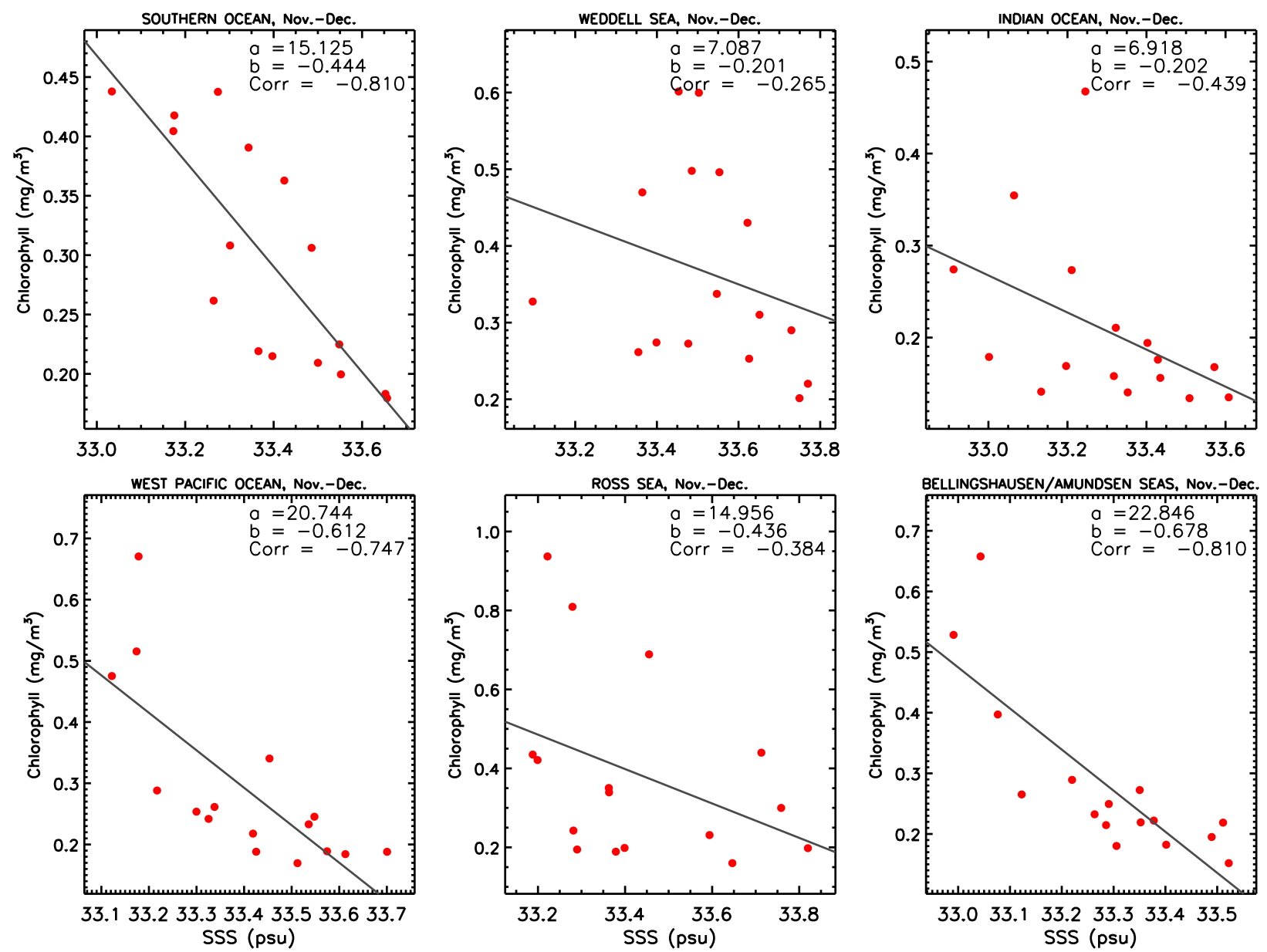

FIG. 8. Scatterplot of biweekly SSS and Chl $\alpha$ concentration data during rapid decline of sea ice in the months November and December from 2011 to 2015.

also the introduction of iron from glacial runoff (Morley et al. 2020; McGillicuddy et al. 2015). This relationship is even stronger in areas of spring polynyas in the Weddell Sea and the Ross Sea. In the Indian Ocean, west Pacific Ocean, and the
Bellingshausen/Amundsen Seas, there are marked Chl $\alpha$ concentration enhancements along the polar fronts likely caused by the upwelling of nutrients in these regions. This result is consistent with the findings of Woodson and Litvin (2015) that

TABLE 2. Yearly averages of SSS and Chl $\alpha$ concentration in the ice-free band adjacent to the marginal ice zone for the entire Antarctic region and the different sectors.

\begin{tabular}{|c|c|c|c|c|c|c|}
\hline & & $\begin{array}{l}\text { Aug 2011- } \\
\text { May } 2012\end{array}$ & $\begin{array}{c}\text { June } 2012- \\
\text { May } 2013\end{array}$ & $\begin{array}{c}\text { June 2013- } \\
\text { May } 2014\end{array}$ & $\begin{array}{c}\text { June 2014- } \\
\text { May } 2015\end{array}$ & $\begin{array}{c}\text { 4-yr } \\
\text { average }\end{array}$ \\
\hline \multirow[t]{6}{*}{ SSS } & All $\left(>55^{\circ} \mathrm{S}\right)$ & 33.398 & 33.414 & 33.325 & 33.268 & 33.351 \\
\hline & Weddell Sea & 33.497 & 33.480 & 33.396 & 33.301 & 33.418 \\
\hline & Indian Ocean & 33.387 & 33.412 & 33.370 & 33.308 & 33.369 \\
\hline & West Pacific Ocean & 33.473 & 33.447 & 33.343 & 33.300 & 33.391 \\
\hline & Ross Sea & 33.353 & 33.432 & 33.294 & 33.279 & 33.340 \\
\hline & Bellingshausen/Amundsen & 33.305 & 33.259 & 33.240 & 33.183 & 33.247 \\
\hline \multirow[t]{6}{*}{$\operatorname{Chl} \alpha\left(\mathrm{mg} \mathrm{m}^{-3}\right)$} & All $\left(>55^{\circ} \mathrm{S}\right)$ & 0.444 & 0.383 & 0.382 & 0.396 & 0.401 \\
\hline & Weddell Sea & 0.616 & 0.353 & 0.355 & 0.267 & 0.398 \\
\hline & Indian Ocean & 0.458 & 0.233 & 0.249 & 0.370 & 0.328 \\
\hline & West Pacific Ocean & 0.300 & 0.248 & 0.359 & 0.437 & 0.336 \\
\hline & Ross Sea & 0.305 & 0.423 & 0.382 & 0.416 & 0.382 \\
\hline & Bellingshausen/Amundsen & 0.529 & 0.700 & 0.708 & 0.671 & 0.652 \\
\hline
\end{tabular}




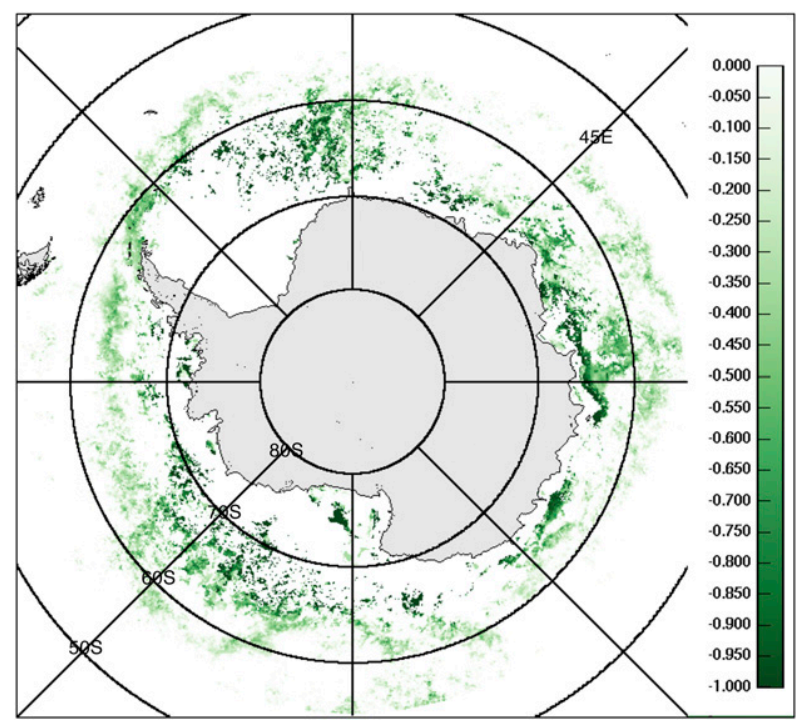

FIG. 9. Map of negative correlations of SSS and Chl $\alpha$ in the Southern Ocean $>55^{\circ} \mathrm{S}$ from August 2011 to June 2015. Only shown are areas that are statistically significant (95\% significance level).

highlight the importance of identifying ocean fronts as biogeochemical hotspots.

\section{2) RELATIONSHIP BETWEEN SST AND CHL $\alpha$ CONCENTRATION}

To gain insight into the relationship between SST and Chl $\alpha$ concentration in the Antarctic region, concurrent data on Chl $\alpha$ concentration and SST were analyzed. The time series from the entire Southern Ocean MIZ in Fig. 10a indicate a strong coherence between the two variables. It appears that surface temperature and $\mathrm{Chl} \alpha$ concentration vary synchronously, with the highest phytoplankton concentration occurring almost simultaneously with the warmest waters. The relationship between SST and Chl $\alpha$ concentration shows a strong positive correlation $(r=0.79)$ when considering the entire Southern Ocean (Fig. 10). The correlation varies significantly from one sector to another with the correlation coefficient being 0.28 and 0.50 for the Weddell Sea and Indian Ocean sectors, respectively. The poor correlation in the Weddell Sea is in part due to large interannual variability of Chl $\alpha$ concentration in summer with relatively low values during the last three years of data, and the relatively early blooms that occurred shortly before 2014. In the Indian Ocean, there is a lag in the Chl $\alpha$ concentration peak (late bloom) relative to SST in 2014 and 2015. The correlations are higher in the west Pacific Ocean, Ross Sea, and Bellingshausen/Amundsen Seas sectors with the correlation coefficients being $0.75,0.66$, and 0.83 , respectively.

Although the relationship between SST and Chl $\alpha$ can largely be characterized as linear, there are some exceptions. For example, across the entire Southern Ocean, there appears to be a $\mathrm{Chl} \alpha$ concentration optimum near $-1.1^{\circ} \mathrm{C}$. Overall, however, the relatively strong positive relationship between the two variables indicates that in addition to SSS, SST has a strong complementary influence on the primary productivity near the marginal ice zone, with the effect being not just a direct influence on growth rates, but also on the acceleration of sea ice retreat that changes the timing and magnitude of bloom onset. In this region, future increases in SST will likely affect productivity in a positive way (Feng et al. 2010), but it is also important to consider the effects of the combination of various climate stressors such as response to repeated exposure to high PAR and UV irradiances over short time scales (Davidson 2006; Moreau et al. 2015) or decreases in surface nutrient supply due to increased vertical stratification (Sarmiento et al. 2004). It is also worth noting that the positive correlation observed in the Southern Ocean MIZ is unique in polar waters since higher Chl $\alpha$ concentration is typically found in colder waters in the lower latitudes (McClain et al. 2004). The rates at which Chl $\alpha$ concentration changes with increases in SST is highest in the Bellingshausen/Amundsen Seas $\left(m=1.55 \mathrm{mg} \mathrm{m}^{-3}{ }^{\circ} \mathrm{C}^{-1}\right)$, followed by the Ross Sea $\left(m=1.51 \mathrm{mg} \mathrm{m}^{-3}{ }^{\circ} \mathrm{C}^{-1}\right)$. These results show the importance of understanding the range of temperature optimum that drives changes in community structure.

\section{3) RELATIONSHIP BETWEEN SSS AND SST}

Although SSS and SST vary independently of one another, it is useful to assess their covariance. The analysis shows a strong relationship between the two variables (Fig. 11). The seasonal variability of SSS is shown to be relatively uniform from one year to another with a summer minimum varying significantly only in the Ross and Bellingshausen/Amundsen sectors. The summer SST distribution in the Ross Sea is sometimes not well defined as in 2013, whereas the summer SST in the Bellingshausen Amundsen Sea varies from a high value of 33.1 in 2012 to 32.3 in 2013. For the entire Southern Ocean, the correlation coefficient between SSS and SST is -0.79 . In the Indian Ocean, west Pacific Ocean, and the Bellingshausen/Amundsen Seas sectors, the correlations are $-0.84,-0.85$, and -0.81 , respectively.

The observed inverse relationship of the two variables is in part because of the impact of SST on sea ice. In particular, SST starts to increase during spring and summer causing sea ice to melt and more meltwater in the MIZ study area (Fig. 12), which contributes to the decrease in summer SSS. Again, the correlations in the Weddell and Ross Seas are relatively low at -0.67 and -0.33 , respectively, likely associated with abrupt ice decline in these sectors that cause the dispersion of ice that melts heterogeneously across the region. There is also strong gyre circulation in both seas that causes the advance and retreat of the ice to be different than in the other sectors. Average SST in the whole Southern Ocean is $-1.17^{\circ} \mathrm{C}$, with warmest mean SST observed in the west Pacific Ocean of $-1.06^{\circ} \mathrm{C}$, followed by the Bellingshausen/Amundsen Seas, and Indian Ocean at $-1.11^{\circ} \mathrm{C}$. Both the Weddell and Ross Seas have the coldest waters at $-1.24^{\circ}$ and $-1.21^{\circ} \mathrm{C}$, respectively. The rate of change between SSS and SST is highest in the west Pacific Ocean and Bellingshausen/Amundsen Seas, with slopes of -0.90 and -0.83 , respectively.

\section{4) RELATIONSHIP BETWEEN SSS AND MARGINAL ICE ZONE AREA}

It is expected for SSS to vary seasonally since the area behind the retreating sea ice should have significantly lower 
(a) Southern Ocean

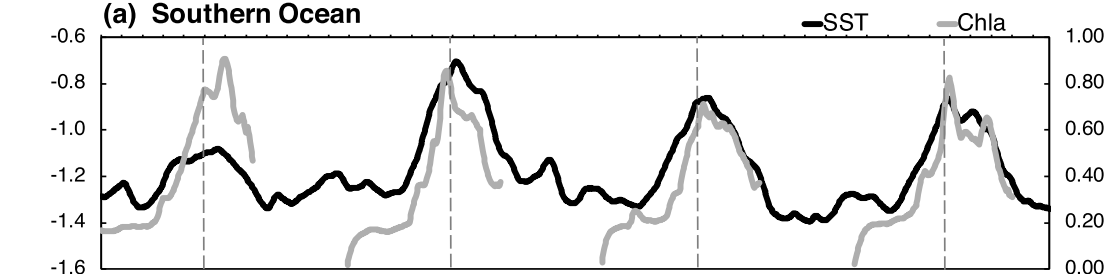

(b) Weddell Sea
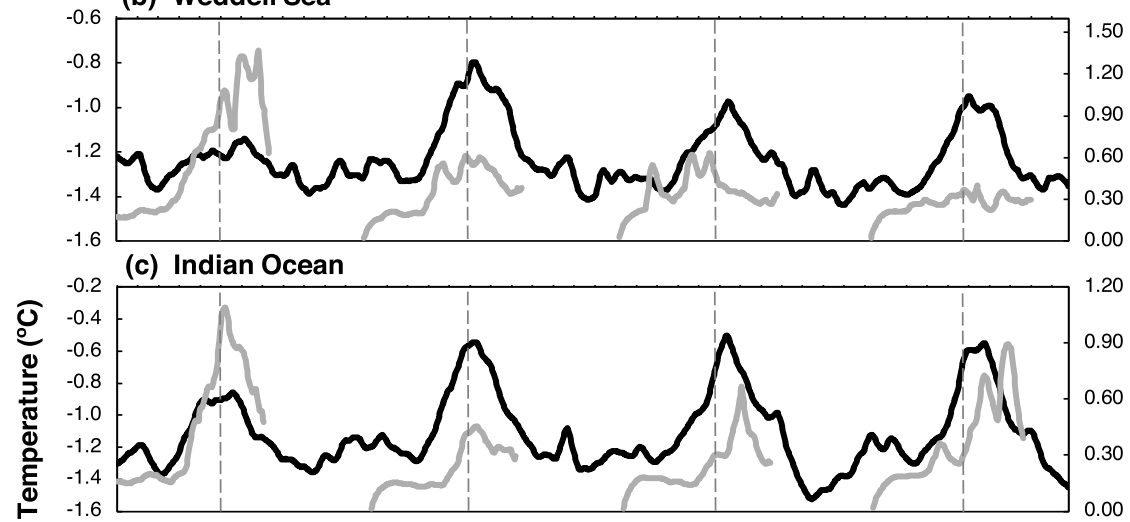

(d) West Pacific Ocean

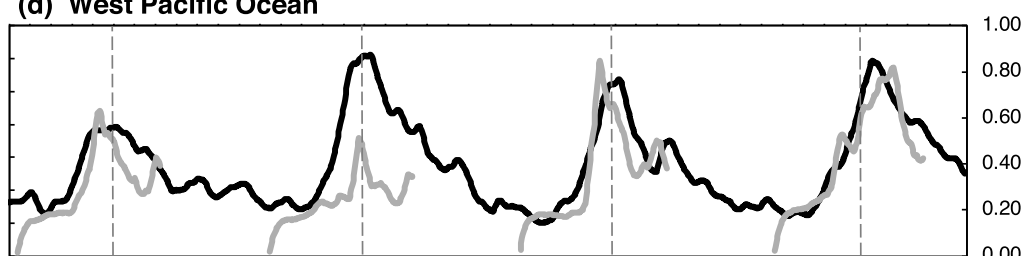

(e) Ross Sea
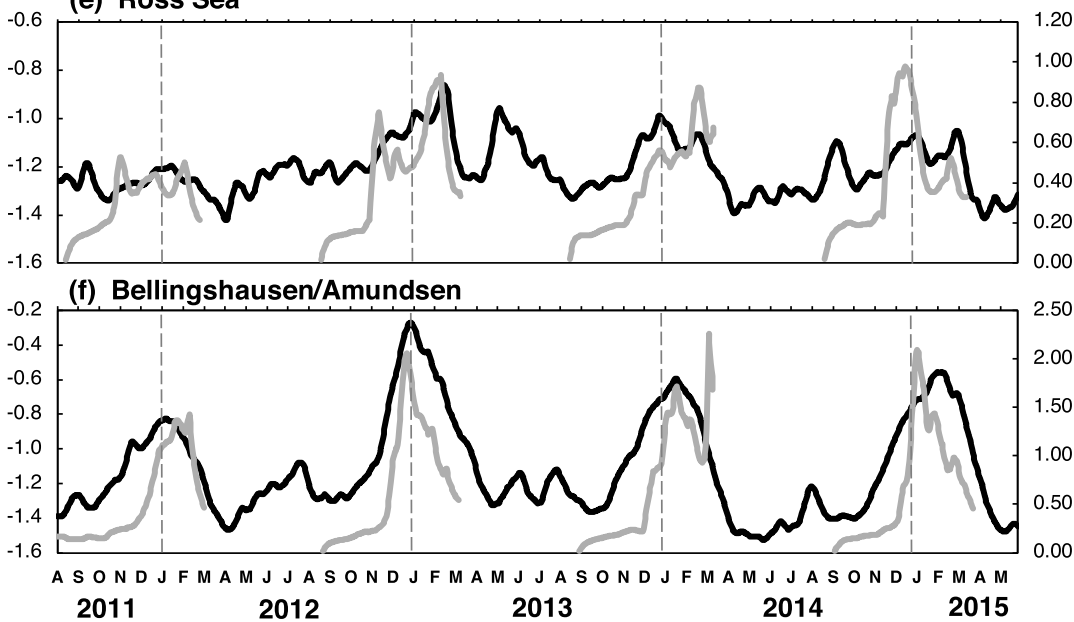
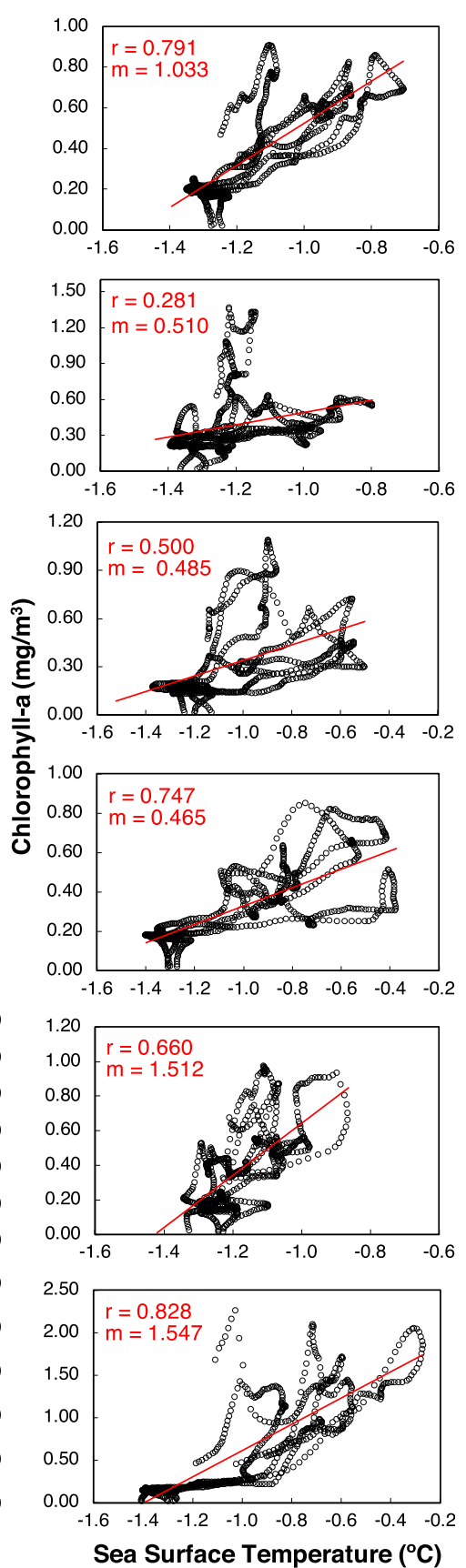

FIG. 10. (left) Time series of SST in black and Chl $\alpha$ concentration in gray from the Southern Ocean MIZ from August 2011 to June 2015 in the (a) Southern Ocean, (b) Weddell Sea, (c) Indian Ocean, (d) west Pacific Ocean, (e) Ross Sea, and (f) Bellingshausen/Amundsen Seas. (right) Corresponding scatterplots of Chl $\alpha$ concentration vs SST with correlation coefficient $(r)$ and slope $(m)$.

salinity as meltwater is introduced. A prominent feature in the MIZ area time series found in Fig. 12 is the sharp increase at the end of spring, which is a feature that emerges in most of the sectors. The timing and magnitude of maximum and minimum MIZ area varies per sector but overall the average MIZ area in the entire Southern Ocean reaches up to 3.8 million $\mathrm{km}^{2}$ during November and December and declines to 1.4 million $\mathrm{km}^{2}$ by
March. For the entire Southern Ocean, the correlation coefficient between SSS and MIZ area is 0.42 , which is mostly influenced by the computed relationship in the Weddell and Ross Seas (0.24 and -0.19 , respectively). The correlation coefficient is highest at 0.78 in the west Pacific Ocean, followed by the Bellingshausen/Amundsen Seas at 0.61. The reason for the relatively poor correlation is the abrupt change in the sea ice 
(a) Southern Ocean

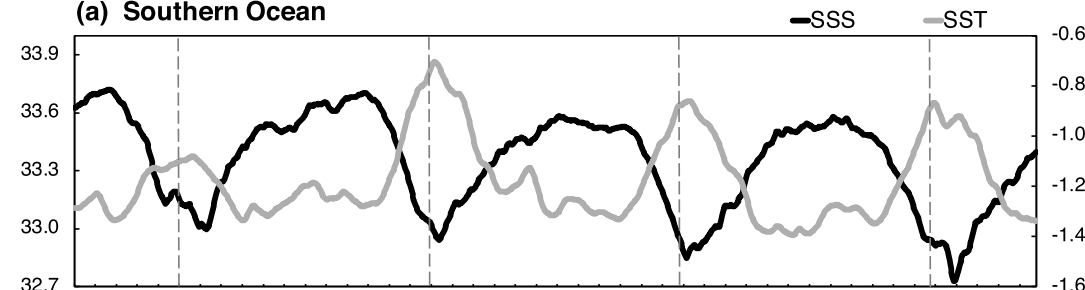

(b) Weddell Sea

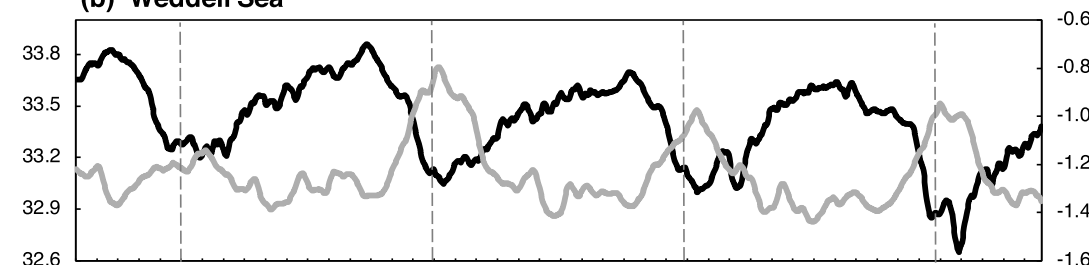

(c) Indian Ocean

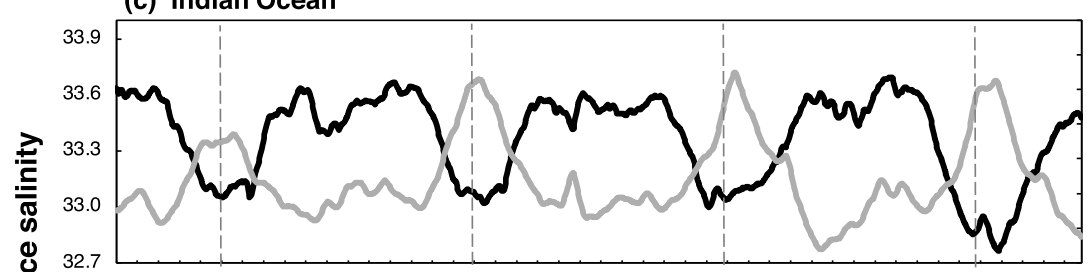

(d) West Pacific Ocean

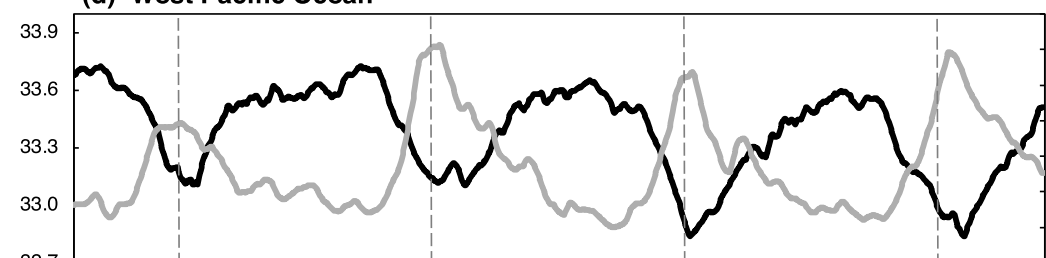

(e) Ross Sea
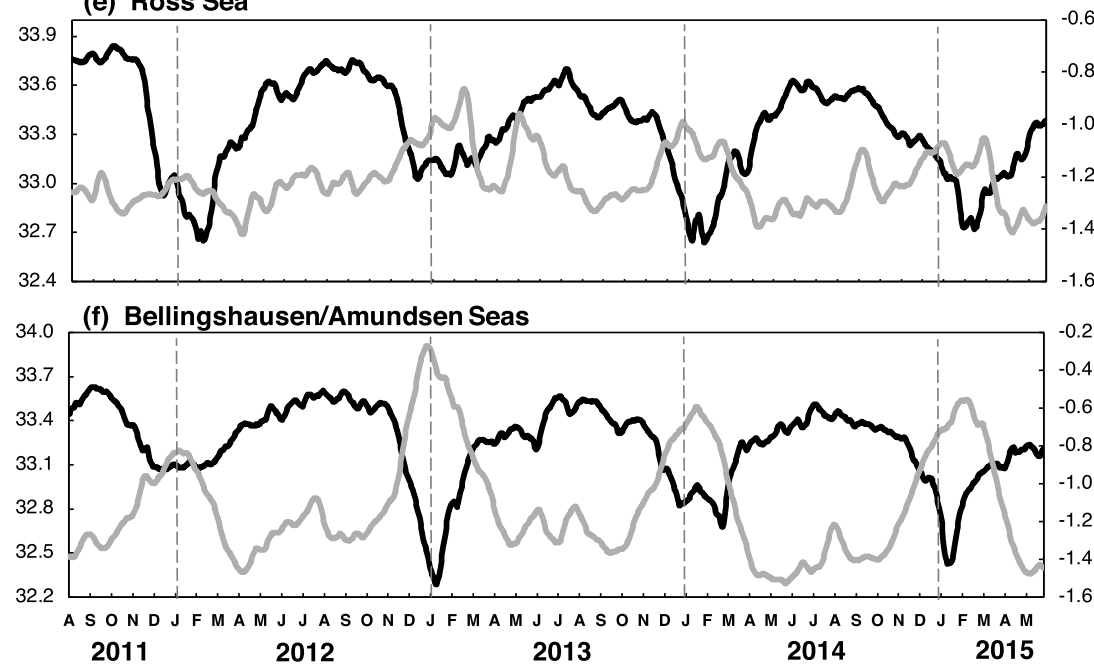
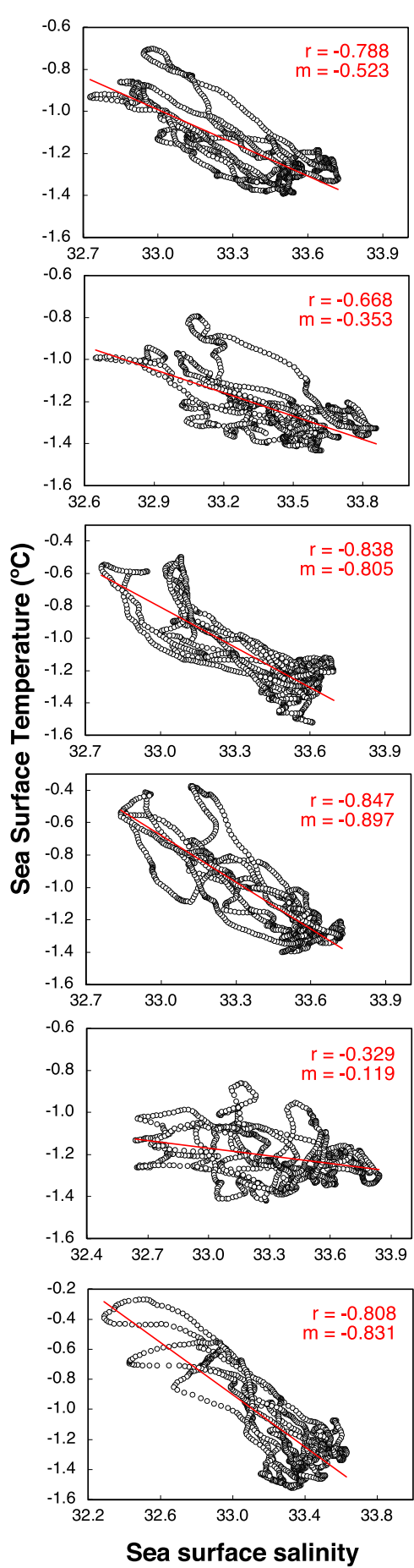

FIG. 11. (left) Time series of SSS in black and SST in gray using data from the Southern Ocean MIZ from August 2011 to June 2015 in the (a) Southern Ocean, (b) Weddell Sea, (c) Indian Ocean, (d) west Pacific Ocean, (e) Ross Sea, and (f) Bellingshausen/Amundsen Seas. (right) Corresponding scatterplots of SSS vs SST and correlation coefficient $(r)$ and slope $(m)$.

cover that is not reflected in the SSS data. In particular, SSS data change smoothly with time with values not lower than that of meltwater values compared to the sometimes drastic changes in the sea ice area.
The large-scale melt of sea ice over a short period and the unpredictable melt rates that are spatially variable also contribute to the regional variability. The decay processes in these regions do not simply increase monotonically from north to 
(a) Southern Ocean

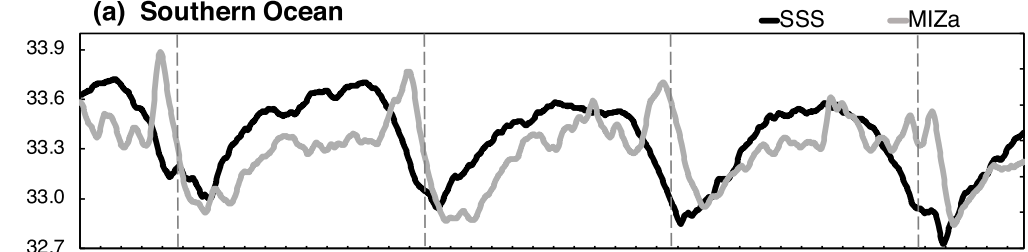

(b) Weddell Sea

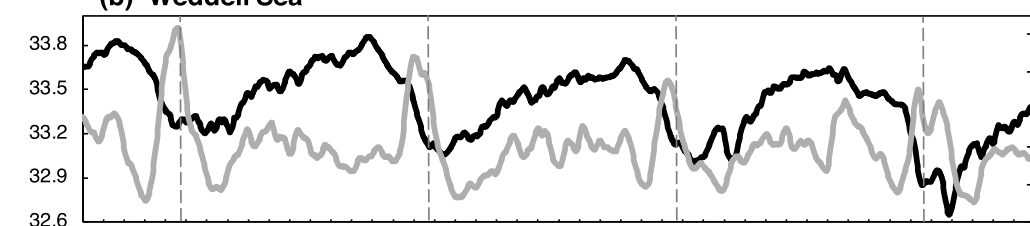

(c) Indian Ocean

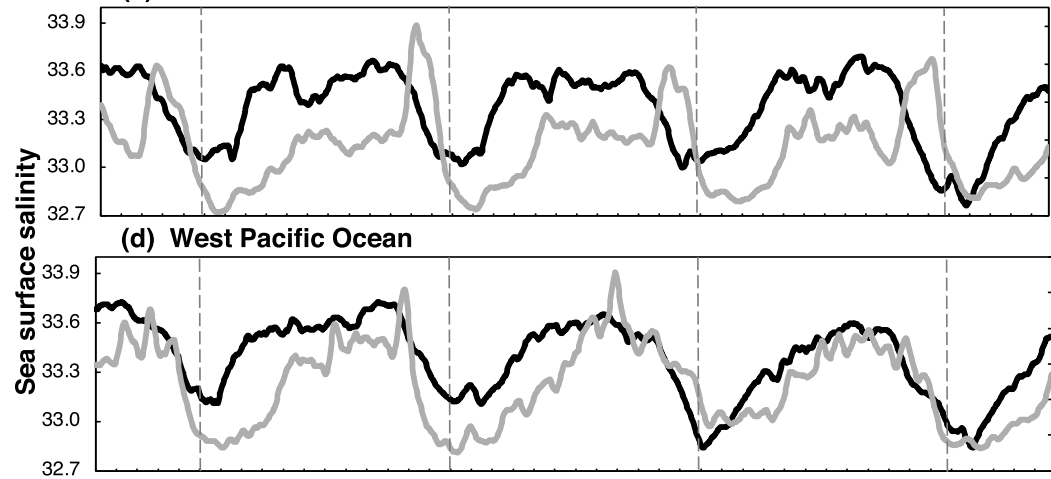

(e) Ross Sea

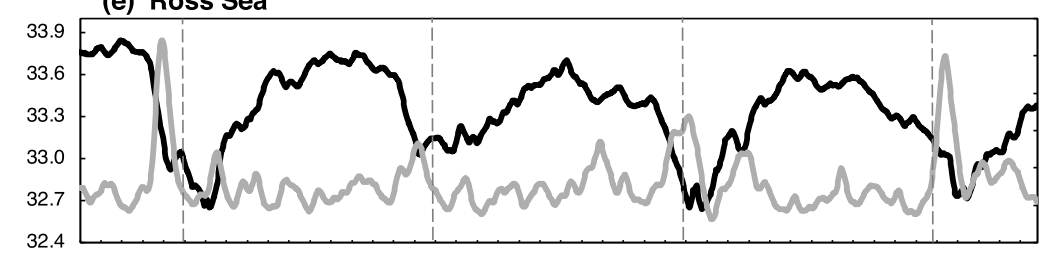

(f) Bellingshausen/Amundsen Seas

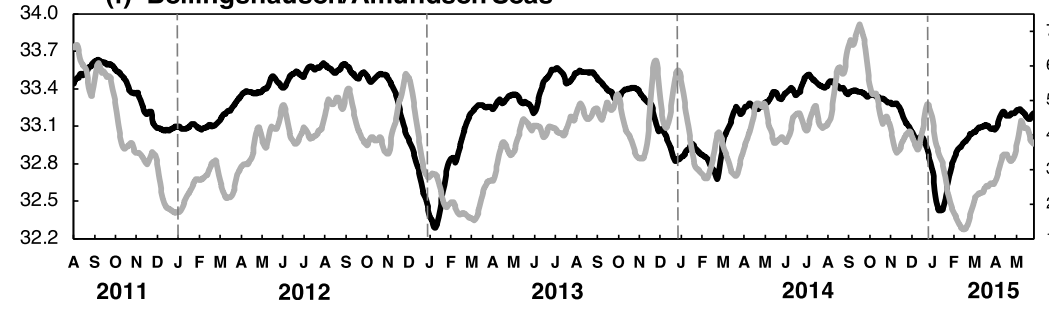

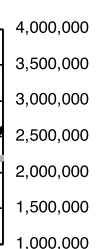

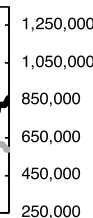

250,000

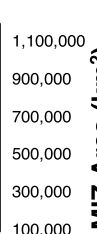

100,000

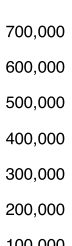

100,000

$1,400,000$

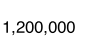

$1,000,000$

800,000

600,000

400,000

200,000

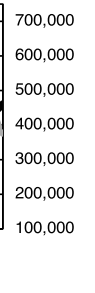

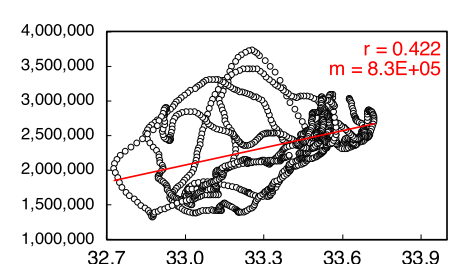
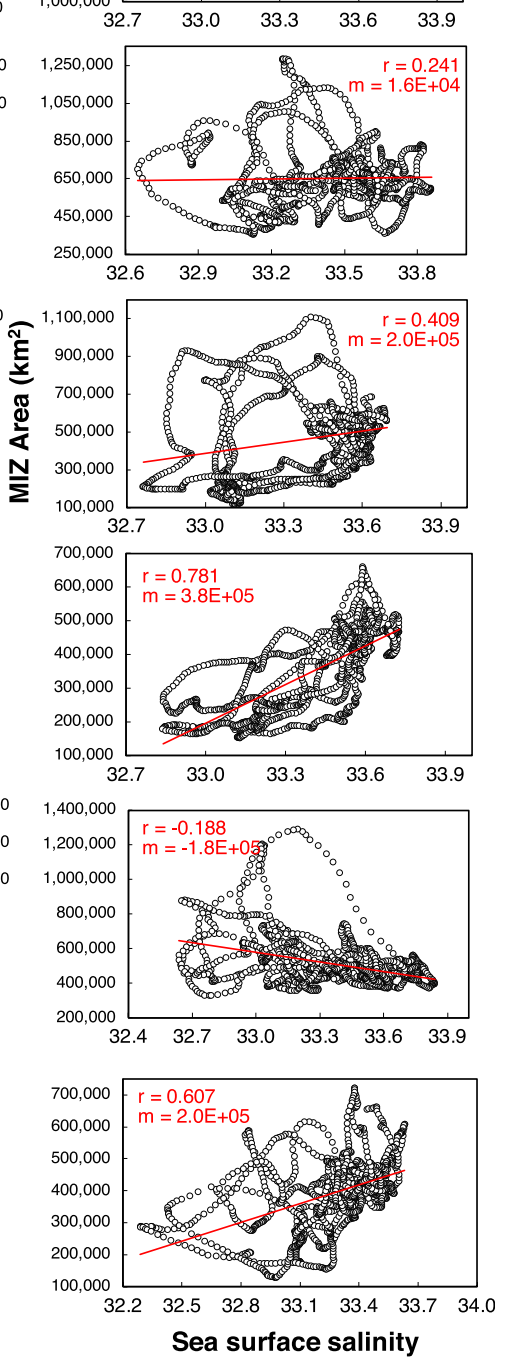

FIG. 12. (left) Time series of SSS in black and area of MIZ in gray from August 2011 to June 2015 in the (a) Southern Ocean, (b) Weddell Sea, (c) Indian Ocean, (d) west Pacific Ocean, (e) Ross Sea, and (f) Bellingshausen/Amundsen Seas. (right) Corresponding scatterplots of SSS vs Area of MIZ and correlation coefficient $(r)$ and slope $(m)$.

south, but also evolve systematically from west to east as influenced by winds and surface currents. Increases in wind and wave action also increase MIZ area by accelerating the breakup and dispersal of sea ice by waves (Dobrynin et al. 2012; Stroeve et al. 2016). In spring, the sharp increases in MIZ area (Fig. 12a) could be a useful indicator of the onset of retreat as initiated by large waves that propagate through the sea ice that break up ice floes. The timing of sea ice retreat can also potentially contribute to the nonuniform changes observed between sectors. For example, the ice-free seasons in the Bellingshausen/Amundsen Seas are found to be lengthening to about three months because of early retreat and later advance. The opposite is true for the western Ross Sea, which experiences shorter ice-free seasons ( $\sim 2.6$ months shorter) because sea ice retreats later and advances earlier (Stammerjohn et al. 2012).

\section{Discussion and conclusions}

We use newly available satellite-derived SSS data together with concurrent Chl $\alpha$ concentration from MODIS Aqua, NOAA Optimum Interpolation Sea Surface Temperature, and 
sea ice concentration data from SSM/I to study the large-scale variability of the physical and biological characteristics of the Southern Ocean and its marginal ice zone. Spatial distributions of the parameters show meridional variations in SSS and SST, with the freshest and coldest values found closest to the ice edge. The seasonal spring and summer phytoplankton blooms are observed mostly along the sea ice margins, and along coastal polynya areas in the Ross Sea, Weddell Sea, and Bellingshausen/Amundsen Seas. While deep waters upwell to the surface in the Indian and west Pacific Oceans dense waters sink and become bottom waters in the Ross Sea, Weddell Sea, and Prydz Bay-Amery Ice Shelf polynya regions. These bottom water production sites are consistently characterized by cold and saline waters in the seasonal maps. The data show the presence of a consistent salinity peak in October (the beginning of austral spring), when sea ice cover usually reaches its maximum extent. Another peak is unexpectedly observed in April, which is a time period when seasonal increases in winds and storminess occurs and vertical entrainment in the Southern Ocean is at its seasonal maximum. Atmospheric forcing of SSS through changes in $P-E$ do not appear to be a critical determinant of the seasonal salinity cycle.

In the assessment of the temporal variability and relationships between the parameters, we observed a strong negative correlation between Chl $\alpha$ concentration and SSS, with a correlation coefficient of -0.87 when considering the entire Southern Ocean MIZ. This is in part driven by similarities in the seasonal cycles of the two variables, the evolution of which is well captured by the contributions from changes in sea ice and oceanic processes. The high correlation, however, indicates the important and likely influence of low-salinity meltwater that along with ample nutrients (which may include iron) and increased irradiance would cause the occurrence of phytoplankton blooms. Although such a relationship has been speculated and observed from limited in situ data, this is the first time that the strength and spatial characteristics of the relationship has been quantified on a large scale, which is only possible through the advent of satellite SSS data. Regionally, however, the correlation coefficients are variable and range from -0.31 in the Weddell Sea to -0.85 in the Bellingshausen/ Amundsen Seas, indicating that other factors modulate the effect of meltwater on chlorophyll concentrations. The weak correlation in the Weddell Sea is likely associated with the particularly abrupt decline in the sea ice cover in the region in spring and summer making the distribution of meltwater spatially complex. Note that the Bellingshausen/Amundsen Seas had the freshest waters at 33.18 in June-May 2015 when the $\mathrm{Chl} \alpha$ concentration was high at $0.67 \mathrm{mg} \mathrm{m}^{-3}$. On the other hand, the SSS in the Indian Ocean was relatively high at 33.41 when the Chl $\alpha$ concentration was lowest at $0.23 \mathrm{mg} \mathrm{m}^{-3}$ during the June 2012-May 2013 period. The spatial distribution of the phytoplankton blooms relative to low SSS also follows a meridional distribution near the vicinity of the ACC. This shows the effect of Ekman advection that acts to decrease salinity in most of the regions close to the ice edge. Decreases in the correlation coefficient near the northern boundary suggests that more saline waters are entrained into the mixed layer from the subsurface from the year-round westerly winds.
The Chl $\alpha$ concentration is also shown to be highly correlated with SST, suggesting increased phytoplankton activity in relatively warm waters. Although density is mostly driven by salinity in these regions, warming can also help increase the buoyancy of surface waters, which prevents phytoplankton from being mixed down into depths below the euphotic zone. Generally calmer spring and summer weather also reduces winddriven disturbances that can disrupt phytoplankton blooms that are free-floating in the buoyant surface water. Although most of the data points follow a linear pattern, which could imply that Chl $\alpha$ concentration increases with increasing surface temperature, it is also critical to recognize the interactive effects of other factors such as increase in iron-rich waters entrained into the euphotic zone from glacial melt and icebergs that can also positively affect phytoplankton communities. As discussed, the positive correlation observed in the Southern Ocean MIZ is distinctive in that in lower latitudes, Chl $\alpha$ concentration tend to decline when the water is warmer. This highlights the importance of understanding the range of temperature optimums that drive community structure and shifts. It has also been reported that frazil ice exhibits significant green algal accumulation (DeJong et al. 2018). Such ice has been referred to as green frazil ice and is apparently abundant in coastal areas around Antarctica during the late summer seasons. The algorithm used to detect the greenness has not been validated, but even if this is true, the Chl $\alpha$ concentration algorithm that was used to generate the data for this study is only valid in ice-free ocean surfaces and will not be able to provide an estimate of the distribution of green frazil ice.

An inverse relation between SSS and SST is observed in the Southern Ocean MIZ with a correlation coefficient of -0.79 , mostly observed during start of spring and all of summer. This is driven by the impact of SST on sea ice with spring and summer increases in SST helping with the onset and propagation of sea ice retreat, which subsequently causes freshening of the ocean surface. On the other hand, when the surface temperature is cold and sea ice is advancing, SSS is usually high because of the absence of meltwater, and the fact that data come from lower latitudes where the values are usually higher. Regional variability of the MIZ area also indicates that the sea ice decay and growth processes in every sector are different and are increasingly being influenced by intensification of wind and wave action.

Overall, the results of this study illustrate the value of a combined use of parameters from satellite sensors in gaining a better understanding of the physical and biological processes in the Southern Ocean, especially in its highly dynamic MIZ. The analysis of the spatial and temporal distribution of the parameters provides a robust connection of spring and summer chlorophyll blooms within low salinity surface layers-an ideal platform for photosynthesis. This is in addition to the widely known limitations that light and availability of the trace metal iron impose on phytoplankton distribution in the Southern Ocean (Wu et al. 2019; Moreno et al. 2020). The availability of concurrent SSS, Chl $\alpha$ concentration, and SST data is also especially important because it enables the assessment and quantification of the influence of SSS and SST on Chl $\alpha$ concentration, which can help in our ability to project how primary 
productivity in polar oceans can be influenced by the changing sea ice cover and anthropogenic global warming. In a continually freshening Southern Ocean, we also acknowledge that the response of phytoplankton to physical drivers is highly complex and is often coupled with other biotic changes. However, predicting net effects starts with an understanding of individual spatial and temporal relationships that define the timing and structure of phytoplankton communities within the vast expanse of the Southern Ocean.

Acknowledgments. We are grateful to the ACM/SIGHPC Intel Computational and Data Science Fellowship and for the NASA Ocean Biology and Biochemistry Program for providing funding support. The Aquarius L2 end-of-mission v.5.0 satellite product that served as the input source data in processing AqGSFC is from the NASA PO.DAAC. The chlorophyll$\alpha$ concentration measured by the MODIS Aqua is provided by the Ocean Biology Processing Group, NASA Goddard Space Flight Center. The sea ice concentration known as SB2 is provided by the NSIDC, while the SST from AVHRR by the NOAA NCEI.

Data availability statement. The AqGSFC Southern Hemisphere SSS data can be accessed at https://earth.gsfc.nasa.gov/cryo/ data/high-latitude-sea-surface-salinity. The estimates of the other parameters are available as shown here: MODIS Aqua chlorophyll- $\alpha$ concentration (https:/oceandata.sci.gsfc.nasa.gov/ MODIS-Aqua/Mapped/Daily/4km/chlor_a/), SB2 sea ice concentration (https://doi.org/10.5067/7Q8HCCWS4I0R), and AVHRR OI SST (https://www.ncei.noaa.gov/data/seasurface-temperature-optimum-interpolation/v2.1/access/avhrr/).

\section{REFERENCES}

Arrigo, K. R., and G. L. van Dijken, 2004: Phytoplankton dynamics within 37 Antarctic coastal polynya systems. J. Geophys. Res., 108, 3271, https://doi.org/10.1029/2002JC001739

,-- , and S. Bushinsky, 2008: Primary production in the Southern Ocean, 1997-2006. J. Geophys. Res., 113, C08004, https://doi.org/10.1029/2007JC004551.

Banzon, V., T. M. Smith, T. M. Chin, C. Liu, and W. Hankins, 2016: A long-term record of blended satellite and in situ sea-surface temperature for climate monitoring, modeling and environmental studies. Earth Syst. Sci. Data, 8, 165-176, https:// doi.org/10.5194/essd-8-165-2016.

Belward, A., M. A. Bourassa, M. Dowell, and S. Briggs, 2016: The Global Observing System for climate: Implementation needs GCOS-200, accessed 3 December 2019, https://unfccc.int/files/ science/workstreams/systematic_observation/application/pdf/ gcos_ip_10oct2016.pdf.

Bintanja, R., G. J. van Oldenborgh, S. S. Drijfhout, B. Wouters, and C. A. Katsman, 2013: Important role for ocean warming and increased ice-shelf melt in Antarctic sea ice expansion. Nat. Geosci., 6, 376-379, https://doi.org/10.1038/ngeo1767.

,$- \ldots$, and C. Katsman, 2015: The effect of increased fresh water from Antarctic ice shelves on future trends in Antarctic sea ice. Ann. Glaciol., 56, 120-126, https://doi.org/10.3189/ 2015AoG69A001.

Comiso, J. C., 2000: Variability and trends in Antarctic surface temperatures from in situ and satellite infrared measurements. J. Climate, 13, 1674-1696, https://doi.org/10.1175/1520-0442(2000) $013<1674$ :VATIAS $>2.0$.CO;2.
— 2017: Bootstrap Sea Ice Concentrations from Nimbus-7 SMMR and DMSP SSM/I-SSMIS, version 3. NASA National Snow and Ice Data Center Distributed Active Archive Center, accessed July 2018, https://doi.org/10.5067/7Q8HCCWS4I0R.

_ and F. Nishio, 2008: Trends in the sea ice cover using enhanced and compatible AMSR-E, SSM/I, and SMMR data. J. Geophys. Res., 113, C02S07, https://doi.org/10.1029/2007JC004257.

_ C. McClain, C. Sullivan, J. Ryan, and C. L. Leonard, 1993: CZCS pigment concentrations in the Southern Ocean and their relationships to some geophysical parameters. J. Geophys. Res., 98, 2419-2451, https://doi.org/10.1029/92JC02505.

- W. Meier, and R. Gersten, 2017: Variability and trends in the Arctic sea ice cover: Results from different techniques. J. Geophys. Res., 122, 6883-6900, https://doi.org/10.1002/ 2017JC012768.

Copernicus Climate Change Service (C3S), 2017: ERA5: Fifth generation of ECMWF atmospheric reanalyses of the global climate. Copernicus Climate Change Service Climate Data Store (CDS), accessed 1 December 2020, https://cds.climate. copernicus.eu/\#!/search?text=ERA5\&type $=$ dataset.

Davidson, A. T., 2006: Effects of ultraviolet radiation on microalgal growth. Algal Culture, Analogues of Blooms and Applications, Vol. 2, D. V. Subba Rao, Ed., Science Publishers, 715-768.

DeJong, H. B., R. B. Dunbar, and E. A. Lyons, 2018: Late summer frazil ice-associated algal blooms around Antarctica. Geophys. Res. Lett., 45, 826-833, https://doi.org/10.1002/2017GL075472.

Deppeler, S. L., and A. T. Davidson, 2017: Southern Ocean phytoplankton in a changing climate. Front. Mar. Sci., 4, 40, https://doi.org/10.3389/fmars.2017.00040.

Dobrynin, M., J. Murawsky, and S. Yang, 2012: Evolution of the global wind wave climate in CMIP5 experiments. Geophys. Res. Lett., 39, L18606, https://doi.org/10.1029/2012GL052843.

Dong, S., S. L. Garzoli, and M. Baringer, 2009: An assessment of the seasonal mixed layer salinity budget in the Southern Ocean. J. Geophys. Res., 114, C12001, https://doi.org/10.1029/ 2008JC005258.

Durack, P. J., and S. E. Wijffels, 2010: Fifty-year trends in global ocean salinities and their relationship to broad-scale warming. $J$. Climate, 25, 4342-4362, https://doi.org/10.1175/2010JCLI3377.1.

Feng, Y., and Coauthors, 2010: Interactive effects of iron, irradiance and $\mathrm{CO}_{2}$ on Ross Sea phytoplankton. Deep Sea Res. I, 57, 368-383, https://doi.org/10.1016/j.dsr.2009.10.013.

Frederiksen, J. S., and C. S. Frederiksen, 2007: Interdecadal changes in Southern Hemisphere winter storm track modes. Tellus, 59A, 559-617, https://doi.org/10.1111/j.1600-0870.2007.00264.x.

Garcia-Eidell, C., J. C. Comiso, E. Dinnat, and L. Brucker, 2017: Satellite observed salinity distributions at high latitudes in the Northern Hemisphere: A comparison of four products. J. Geophys. Res. Oceans, 122, 7717-7736, https://doi.org/10.1002/2017JC013184.

,,--- , and $\longrightarrow, 2019$ : Sea surface salinity distribution in the Southern Ocean as observed from space. J. Geophys. Res. Oceans, 124, 3186-3205, https://doi.org/10.1029/2018JC014510.

Gille, S. T., 2008: Decadal-scale temperature trends in the Southern Hemisphere ocean. J. Climate, 21, 4749-4765, https://doi.org/ 10.1175/2008JCLI2131.1.

Haumann, F. A., N. Gruber, M. Münnich, I. Frenger, and S. Kern, 2016: Sea-ice transport driving Southern Ocean salinity and its recent trends. Nature, 537, 89-92, https://doi.org/10.1038/ nature19101.

Hiscock, M. R., and Coauthors, 2003: Primary productivity and its regulation in the Pacific sector of the Southern Ocean. Deep-Sea Res. II, 50, 533-558, https://doi.org/10.1016/ S0967-0645(02)00583-0. 
Hobbs, W. R., R. Massom, S. Stammerjohn, P. Reid, G. Williams, and W. Meier, 2016: A review of recent changes in Southern Ocean sea ice, their drivers and forcings. Global Planet. Change, 143, 228-250, https://doi.org/10.1016/j.gloplacha.2016.06.008.

Holland, P. R., and R. Kwok, 2012: Wind-driven trends in Antarctic sea-ice drift. Nat. Geosci., 5, 872-875, https://doi.org/ 10.1038/ngeo1627.

Hu, C., Z. Lee, and B. Franz, 2012: Chlorophyll $a$ algorithms for oligotrophic oceans: A novel approach based on three-band reflectance difference. J. Geophys. Res., 117, C01011, https:// doi.org/10.1029/2011JC007395.

Jacobs, S. S., and J. C. Comiso, 1997: Climate variability in the Amundsen and Bellingshausen Seas. J. Climate, 10, 697-709, https://doi.org/10.1175/1520-0442(1997)010<0697: CVITAA $>2.0 . \mathrm{CO} ; 2$.

- C. F. Giulivi, and P. A. Mele, 2002: Freshening of the Ross Sea during the late 20th century. Science, 297, 386-389, https:// doi.org/10.1126/science.1069574.

Maykut, G., and N. Untersteiner, 1971: Some results from a timedependent thermodynamic model of sea ice. J. Geophys. Res., 76, 1550-1575, https://doi.org/10.1029/JC076i006p01550.

McClain, C. R., G. C. Fieldman, and S. B. Hooker, 2004: An overview of the SeaWiFS project and strategies for producing a climate research quality global ocean bio-optical time series. Deep-Sea Res. II, 51, 5-42, https://doi.org/10.1016/j.dsr2.2003.11.001.

McGillicuddy, D. J., and Coauthors, 2015: Iron supply and demand in an Antarctic shelf ecosystem. Geophys. Res. Lett., 42, 80888097, https://doi.org/10.1002/2015GL065727.

Meissner, T., F. Wentz, and D. Le Vine, 2018: The salinity retrieval algorithms for the NASA Aquarius version 5 and SMAP version 3 releases. Remote Sens., 10, 1121, https://doi.org/10.3390/rs10071121.

Moreau, S., B. Mostajir, S. Bélanger, I. R. Schloss, M. Vancoppenolle, S. Demers, and G. A. Ferreyra, 2015: Climate change enhances primary production in the western Antarctic Peninsula. Global Change Biol., 21, 2191-2205, https://doi.org/10.1111/gcb.12878.

Moreno, C. M., W. Gong, N. R. Cohen, K. DeLong, and A. Marchetti, 2020: Interactive effects of iron and light limitation on the molecular physiology of the Southern Ocean diatom Fragilariopsis kerguelensis. Limnol. Oceanogr., 65, 1511-1531, https://doi.org/10.1002/lno.11404.

Morley, S. A., and Coauthors, 2020: Global drivers on Southern Ocean ecosystems: Changing physical environments and anthropogenic pressures in an Earth system. Front. Mar. Sci., 7, 547188, https://doi.org/10.3389/fmars.2020.547188.

Nakayama, Y., R. Timmermann, and H. H. Hellmer, 2020: Impact of West Antarctic ice shelf melting on Southern Ocean hydrography. Cryosphere, 14, 2205-2216, https://doi.org/10.5194/ tc-14-2205-2020.

NASA OBPG, 2014: MODIS-Aqua Ocean Color Data; NASA Goddard Space Flight Center, Ocean Ecology Laboratory, Ocean Biology Processing Group, accessed 4 January 2019, https://doi.org/10.5067/AQUA/MODIS_OC.2014.0.

O'Reilly, J. E., S. Maritorena, B. G. Mitchell, D. A. Siegel, K. L. Carder, S. A. Garver, M. Kahru, and C. R. McClain, 1998: Ocean color chlorophyll algorithms for SeaWiFS. J. Geophys. Res., 103, 24 937-24 953, https://doi.org/10.1029/98JC02160.

Parkinson, C. L., 2019: A 40-y record reveals gradual Antarctic sea ice increases followed by decreases at rates far exceeding the rates seen in the Arctic. Proc. Natl. Acad. Sci. USA, 116, 14 414-14 423, https://doi.org/10.1073/pnas.1906556116.

_, and W. M. Washington, 1979: A large-scale numerical model of sea ice. J. Geophys. Res., 84, 311-337, https://doi.org/ 10.1029/JC084iC01p00311.
— trends, 1979-2010. Cryosphere, 6, 871-880, https://doi.org/ 10.5194/tc-6-871-2012.

Purich, A., M. H. England, W. Cai, A. Sullivan, and P. J. Durack, 2018: Impacts of broad-scale surface freshening of the Southern Ocean in a coupled climate model. J. Climate, 31, 2613-2632, https://doi.org/10.1175/JCLI-D-17-0092.1.

Reynolds, R. W., N. A. Rayner, T. M. Smith, D. C. Stokes, and W. Wang, 2002: An improved in situ and satellite SST analysis for climate. J. Climate, 15, 1609-1625, https://doi.org/10.1175/ 1520-0442(2002)015<1609:AIISAS > 2.0.CO;2.

Sakshaug, E., 1994: Discussant's report: Primary production in the Antarctic pelagial-A view from the north. Southern Ocean Ecology: The BIOMASS Perspective, S. Z. El-Sayed, Ed., Cambridge University Press, 125-126.

Sallée, J.-B., K. G. Speer, and S. R. Rintoul, 2010: Zonally asymmetric response of the Southern Ocean mixed-layer depth to the Southern Annular Mode. Nat. Geosci., 3, 273-279, https:// doi.org/10.1038/ngeo812.

Sarmiento, J. L., and Coauthors, 2004: Response of ocean ecosystems to climate warming. Global Biogeochem. Cycles, 18, GB3003, https://doi.org/10.1029/2003GB002134.

Siegel, D. A., K. O. Buesseler, S. C. Doney, S. F. Sailley, M. J. Behrenfeld, and P. W. Boyd, 2014: Global assessment of ocean carbon export by combining satellite observations and foodweb models. Global Biogeochem. Cycles, 28, 181-196, https:// doi.org/10.1002/2013GB004743.

Smith, W. O., Jr., and D. M. Nelson, 1985: Phytoplankton bloom produced by a receding ice edge in the Ross Sea: Spatial coherence with the density field. Science, 227, 163-166, https:// doi.org/10.1126/science.227.4683.163.

- , and - 1986: Importance of ice edge phytoplankton production in the Southern Ocean. BioScience, 36, 251-257, https://doi.org/10.2307/1310215.

— (Antarctica) polynya during austral spring. Geophys. Res. Lett., 24, 233-236, https://doi.org/10.1029/96GL03926.

-_, and J. C. Comiso, 2008: The influence of sea ice on primary production in the Southern Ocean: A satellite perspective. J. Geophys. Res., 113, C05S93, https://doi.org/ 10.1029/2007JC004251.

, R. T. Barber, M. R. Hiscock, and J. Marra, 2000: The seasonal cycle of phytoplankton biomass and primary productivity in the Ross Sea, Antarctica. Deep-Sea Res. II, 47, 3119-3140, https://doi.org/10.1016/S0967-0645(00)00061-8.

Son, S.-W., N. Tandon, M. Lorenzo, and D. Waugh, 2009: Ozone hole and Southern Hemisphere climate change. Geophys. Res. Lett., 36, L15705, https://doi.org/10.1029/2009GL038671.

Stammerjohn, S., R. Massom, D. Rind, and D. Martinson, 2012: Regions of rapid sea ice change: An inter-hemispheric seasonal comparison. Geophys. Res. Lett., 39, L06501, https:// doi.org/10.1029/2012GL050874.

Stroeve, J. C. and W. N. Meier. 2018: Sea Ice Trends and Climatologies from SMMR and SSM/I-SSMIS, version 3 [ice extent]. NASA National Snow and Ice Data Center Distributed Active Archive Center, accessed 30 December 2020, https:// doi.org/10.5067/IJ0T7HFHB9Y6.

, S. Jenouvrier, G. G. Campbell, C. Barbraud, and K. Delord, 2016: Mapping and assessing variability in the Antarctic marginal ice zone, pack ice and coastal polynyas in two sea ice algorithms with implications on breeding success of snow petrels. Cryosphere, 10, 1823-1843, https://doi.org/10.5194/tc-101823-2016. 
Strong, C., and I. G. Rigor, 2013: Arctic marginal ice zone trending wider in summer and narrower in winter. Geophys. Res. Lett., 40, 4864-4868, https://doi.org/10.1002/grl.50928.

Sullivan, C. W., C. R. McClain, J. C. Comiso, and W. O. Smith, 1988: Phytoplankton standing crops within an Antarctic ice edge assessed by satellite remote sensing. J. Geophys. Res., 93, 12 487-12 498, https://doi.org/10.1029/JC093iC10p12487.

Taylor, M. H., M. Losch, and A. Bracher, 2013: On the drivers of phytoplankton blooms in the Antarctic marginal ice zone: A modeling approach. J. Geophys. Res. Oceans, 118, 63-75, https://doi.org/10.1029/2012JC008418.

Vernet, M., and Coauthors, 2008: Primary production within the sea-ice zone west of the Antarctic Peninsula: I-Sea ice, summer mixed layer, and irradiance. Deep-Sea Res. II, 55, 2068-2085, https://doi.org/10.1016/j.dsr2.2008.05.021.

Williams, T. D., L. G. Bennetts, V. A. Squire, D. Dumont, and L. Bertino, 2013: Wave-ice interactions in the marginal ice zone. Part II: Numerical implementation and sensitivity studies along 1D transects of the ocean surfaces. Ocean Modell., 71, 92-101, https://doi.org/10.1016/j.ocemod.2013.05.011.
Woodson, C. B., and S. Y. Litvin, 2015: Ocean fronts drive marine fishery production and biogeochemical cycling. Proc. Natl. Acad. Sci. USA, 112, 1710-1715, https://doi.org/10.1073/pnas. 1417143112.

Woolf, D. K., P. E. Land, J. D. Shutler, L. M. Goddijn-Murphy, and C. J. Donlon, 2016: On the calculation of air-sea fluxes of $\mathrm{CO}_{2}$ in the presence of temperature and salinity gradients. J. Geophys. Res. Oceans, 121, 1229-1248, https://doi.org/ 10.1002/2015JC011427.

Wu, M., J. S. P. McCain, E. Rowland, R. Middag, M. Sandgren, A. E. Allen, and E. M. Bertrand, 2019: Manganese and iron deficiency in Southern Ocean Phaeocystis antarctica populations revealed through taxon-specific protein indicators. Nat. Commun., 10, 3582, https://doi.org/10.1038/s41467-019-11426-z.

Zwally, H. J., J. C. Comiso, C. L. Parkinson, W. J. Campbell, F. D. Darsey, and P. Gloersen, 1983: Antarctic Sea Ice, 1973-1976: Satellite passive-microwave observations. NASA SP-459, 206 pp.

,,,--- D. J. Cavalieri, and P. Gloersen, 2002: Variability of Antarctic sea ice 1979-1998. J. Geophys. Res., 107, 3041, https://doi.org/10.1029/2000JC000733. 